\title{
Latitude and Celiac Disease Prevalence: A Meta-analysis and Meta-regression
}

Short title: Latitude and Celiac Disease

Melis G. Celdir, MD ${ }^{1}$, Claire L. Jansson-Knodell, MD², Isabel A. Hujoel, MD¹, Larry J.

Prokop, $\mathrm{MLS}^{3}$, Zhen Wang, $\mathrm{PhD}^{4}$, M. Hassan Murad, MD${ }^{4}$, Joseph A. Murray, MD ${ }^{1}$

${ }^{1}$ Division of Gastroenterology and Hepatology, Mayo Clinic, Rochester, Minnesota

${ }^{2}$ Division of Gastroenterology and Hepatology, Indiana University, Indianapolis, Indiana

${ }^{3}$ Mayo Medical Library, Mayo Clinic, Rochester, Minnesota

${ }^{4}$ Robert D. and Patricia E. Kern Center for the Science of Health Care Delivery, Mayo

Clinic, Rochester, Minnesota

\section{Grant Support: None}

Abbreviations: AGA, amidated gliadin peptide antibodies; CD, celiac disease; DGP, deamidated gliadin peptide; EMA, endomysial antibodies; HLA, human leukocyte antigen; tTGA, tissue transglutaminase antibodies; NA, not applicable

\section{Corresponding Author:}

Joseph A. Murray, M.D.

$2001^{\text {st }}$ Street SW

Rochester, MN 55905

Phone: $507-775-5713$

Fax: 507-266-0350

Email: murray.joseph@mayo.edu

This is the author's manuscript of the article published in final edited form as: 
Disclosures: JAM receives grant support from; Nexpep/ImmusanT Inc, National Institutes of Health, Immunogenix, Takeda Pharmaceutical Inc, Allakos Inc, Oberkotter Foundation, Cour Inc; is a consultant to Bionix, Lilly Research Laboratory, Johnson \& Johnson, Dr. Schar USA Inc, UCB Biopharma, Innovate Biopharmaceuticals, Glenmark Pharmaceuticals, Celimmune, Amgen Intrexon Corporation, Kanyos, and Boehringer Ingelheim; holds patents licensed to Evelo Biosciences Inc; and receives royalties from Torax Medical. The other authors have nothing to disclose.

Writing Assistance: Mayo Clinic Editing Services 


\section{Abstract}

Background and Aims: Latitudinal gradient effect is described for several autoimmune diseases including celiac disease in the United States. However, the association between latitude and global celiac disease prevalence is unknown. We aimed to explore the association between latitude and serology-based celiac disease prevalence through meta-analysis.

Methods: We searched MEDLINE, Embase, Cochrane, and Scopus databases from their beginning through June 29,2018 , to identify screening studies that targeted a general population sample, used serology-based screening tests, and provided a clear location from which we could assign a latitude. Studies were excluded if sampling was based on symptoms, risk factors, or referral. Study selection and data extraction were performed by independent reviewers. The association measures between latitude and prevalence of serology-based celiac disease were evaluated with random-effects metaanalyses and meta-regression.

Results: Of the identified 4,667 unique citations, 128 studies were included, with 155 prevalence estimates representing 40 countries. Celiac disease was more prevalent at the higher latitudes of $51^{\circ}$ to $60^{\circ}$ (relative risk, $1.62 ; 95 \% \mathrm{Cl}: 1.09-2.38$ ) and $61^{\circ}$ to $70^{\circ}$ (relative risk, $2.30 ; 95 \% \mathrm{Cl}: 1.36-3.89)$ compared with the $41^{\circ}$ to $50^{\circ}$ reference level. No statistically significant difference was observed in lower latitudes. When latitude was treated as continuous, we found statistically significant association between CD prevalence and latitude overall in the world $(R R=1.03,95 \% \mathrm{Cl}: 1.01-1.05)$ and subregional analysis of Europe ( $\mathrm{RR}=1.05,95 \% \mathrm{Cl}: 1.02-1.07)$ and North America $(\mathrm{RR}=1.1,95 \% \mathrm{Cl}: 1.0-1.2)$. 
Conclusions: In this comprehensive review of screening studies, we found that higher latitude was associated with greater serology-based celiac disease prevalence.

Keywords: sprue; serum; tissue transglutaminase; epidemiology 


\section{Introduction}

Celiac disease (CD) is a prevalent autoimmune disease triggered by ingested gluten. It is seen mostly in people of European, North African, and Middle Eastern descent. CD prevalence is highly heterogeneous ${ }^{1,2}$. Geoepidemiology of CD can provide insight into pathogenesis and risk factors responsible for its distribution and increasing incidence ${ }^{3}$. Variations in prevalence among populations with similar human leukocyte antigen (HLA) predisposing allele frequencies and genetic backgrounds point to environmental factors that contribute to disease pathogenesis. Previous studies have shown a correlation between gluten consumption and HLA haplotype frequencies that predispose persons to $\mathrm{CD}^{4-6}$. A large part of the variation in worldwide prevalence has yet to be explained.

Increasing autoimmunity in higher geographic latitudes has been reported for multiple sclerosis $^{7}$, rheumatoid arthritis ${ }^{8,9}$, and inflammatory bowel disease ${ }^{10}$. These associations were linked to less solar exposure and resultant vitamin D deficiency that has been shown to predispose to autoimmune states in several diseases ${ }^{11,12}$. A study using National Health and Nutrition Examination Survey data reported a South-North gradient of CD seroprevalence in the United States ${ }^{13}$. The gradient was statistically significant after adjustment for race/ethnicity, sex, age, and income ${ }^{13}$. The latitudinal association with worldwide CD prevalence is unknown. Therefore, we conducted a systematic review and a meta-analysis to examine the association of latitude with CD seroprevalence. 


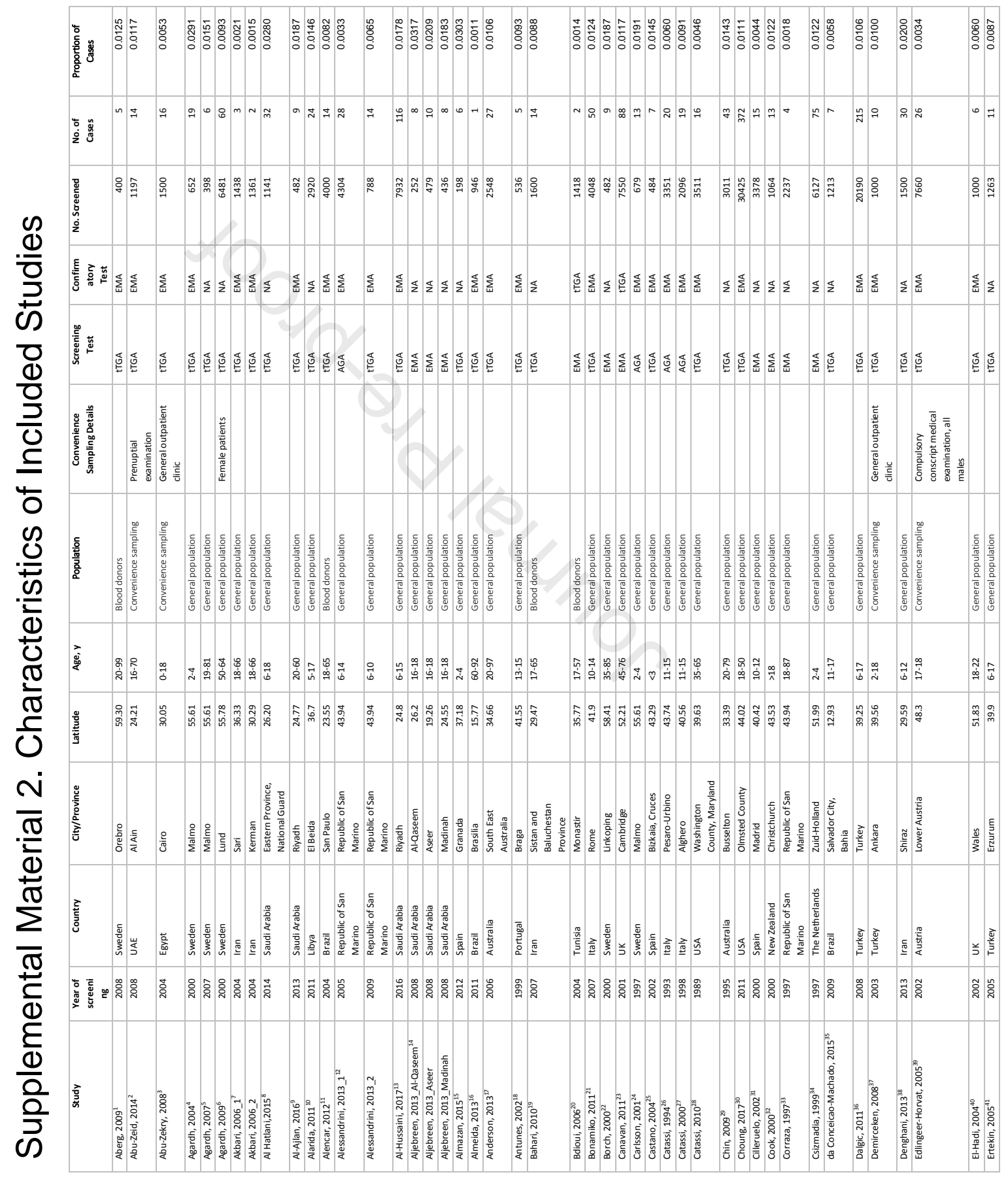


extract the latitudinal and longitudinal coordinates, we used Google Maps to select the geographic "centroid" of the study area and the related latitude and longitude of locations. The variable latitude represents the distance of the study from the equator, in the southern or northern hemisphere. Reviewers [M.G.C, C.L.J-K., I.A.H.] evaluated the studies for methodological quality, using a tool that assesses internal and external validity in prevalence studies ${ }^{18}$ (Supplemental Material 3).

\section{Statistical Analyses}

For studies reporting prevalence by age groups (ie, adults and children), locations, or screening periods, we used each cohort as an independent unit for analysis because they contributed independent information. For studies examining the same population, we included only the most recent or inclusive study or studies with sequential test results, if applicable.

Crude prevalence was determined as the proportion of positive cases to individuals screened. We then normalized the prevalence using log transformation and pooled it using the DerSimonian Laird random-effects methods ${ }^{19}$. Heterogeneity — the variation in study prevalence estimates between studies that is not due to sampling variability —was assessed with the $I^{2}$ statistic ${ }^{20}$. Random-effects meta-regression was carried out to calculate the association for seroprevalence and latitude after control for predefined variables, including age group, year of screening, type of test used to diagnose cases, and study region ${ }^{21}$. Age was categorized as pediatric (0-18 years) and adult ( $>18$ years). Testing method was categorized into 1) sequential with IgA tTGA, AGA, or deamidated gliadin peptide (DGP) antibodies followed by EMA or only EMA testing or 2) 
IgA tTGA testing. Latitudes were categorized based on $10^{\circ}$ increments from the equator. Latitudes from $0^{\circ}$ to $20^{\circ}$ were considered 1 category to increase the number of studies included in the category. A latitudinal level of $41^{\circ}$ to $50^{\circ}$ was set as the reference group to stabilize regression because most studies were conducted within this level. We conducted analyses using latitude and longitude as continuous variables in the regression model for each region and the world. We evaluated the relationship between sample size and prevalence estimates with the funnel plot using the log of the prevalence and Egger's regression test of asymmetry ${ }^{22}$. We used Stata 15 command metareg to perform regression on study-level data and metan for pooled prevalence estimates. Two tailed $P$ values less than .05 were considered statistically significant. Software Stata version 15.1 (StataCorp LLP, College Station, TX) was used for statistical analysis. A map with study locations colored to represent levels of prevalence was created using QGIS 3.12 (http://qgis.org).

\section{Results}

Of the identified 4,667 unique abstracts, we included 155 cohorts from 128 studies that represented 40 countries (Figure 1). The samples used for these cohorts were blood donors $(n=26)$, convenience samples $(n=5)$, and general population $(n=124)$ (Supplemental Material 2). Most studies were from Europe, followed in frequency by Middle East and North Africa (Supplemental Material 4). Most of the studies from Europe and North America provided results based on sequential screening or EMA alone (92/124). Of the 155 cohorts, 65 were pediatric. Prevalence from 1980 through 2016 was available (mean screening year, 2003; range, 1980-2016). Most studies with the screening year before 2000 were from Europe (32/37). Supplemental material 2 
provides details of the 128 studies with references included. All studies had low or moderate risk of bias (Supplemental Material 3).

The worldwide prevalence estimate was $0.79 \%(95 \% \mathrm{Cl}: 0.71-0.88)$ with significant heterogeneity $\left(I^{2}=91.2 \%\right)$ (Table 1, Figure 2). After controlling for the screening test, age group, screening year, and region, the higher latitudes had a statistically significant association with higher CD seroprevalence (Table 2). The relative risk (RR) of CD was $1.62(95 \% \mathrm{Cl}: 1.09-2.38)$ in $51^{\circ}$ to $60^{\circ}$ latitudes and $2.30(95 \% \mathrm{Cl}: 1.36-3.89)$ in $61^{\circ}$ to $70^{\circ}$ latitudes compared with the reference level $41^{\circ}$ to $50^{\circ}$ (Table 2 ). Relative risk in lower latitude categories did not reach statistical significance (Table 2). Positive latitudinal association was observed in the sub-regional analysis of Europe. When latitude was treated as continuous, we found statistically significant association between CD prevalence and latitude overall in the world $(R R=1.03,95 \% \mathrm{Cl}: 1.01-1.05)$ and in the sub-regional analysis of Europe $(R R=1.05,95 \% \mathrm{Cl}: 1.02-1.07)$ and North America $(\mathrm{RR}=1.1,95 \% \mathrm{Cl}: 1.0-1.2)$ (Table 3, Supplemental Material 5 and 6). Longitude was not associated with global $C D$ prevalence $(R R=1.002,95 \% \mathrm{Cl}: 0.998-1.005)$. All study locations are depicted on a world map in Figure 3 and referenced (Supplemental Material 7).

The visual examination of the funnel plot depicting the log of the prevalence plotted against the estimated standard error showed funnel plot asymmetry with significance (Egger's regression test, $p<0.05$ ) indicating that smaller studies tended to have lower prevalence estimates (Supplemental Material 8). 


\section{Discussion}

In this study, we found an overall increase in the risk of CD prevalence globally with increasing latitude after controlling for regions and covariates for study level differences. When latitudes were categorized into intervals of $10^{\circ}$ latitudinal increments, an association was seen between CD prevalence and latitudes above $40^{\circ}$. In regions with lower latitudinal coordinates, North India and the Arabian Peninsula in the Northern Hemisphere and Brazil in the Southern Hemisphere were found to be high-prevalence regions. The higher latitudes were significantly associated with higher CD seroprevalence in the United States and Europe in regional analyses. The prevalence of CD varies widely across regions, likely because of differences in genetic and environmental factors. Overall, genetic inheritance explains $50 \%$ of susceptibility ${ }^{6}$ and among the genetic factors, HLA-DQ2 and HLA-DQ8 haplotypes are the major determinants in the pathogenesis of $C D^{23}$. Increased predisposing HLA frequencies tend to aggregate in regions where the duration of historical wheat consumption is longer ${ }^{4}$, possibly contributing to higher prevalence rates in these regions. After Europe, studies from the region of the Middle East and North Africa provided most of the prevalence estimates included in the analyses.

Genetic predisposition fails to explain differences among and within some regions in the world. In India, although the CD predisposing HLA-DQ frequencies were similar in Northern, Northeastern and Eastern India, CD is reported to be more prevalent in northern regions where wheat intake is higher ${ }^{5}$. On the other hand, despite wheat consumption per capita being highest in North African and Middle Eastern countries, the 
North European regions still have the highest prevalence estimates in this current study. These observations point to combination of factors and unidentified elements that modify disease risk.

Latitude is often used as a surrogate of environmental factors in geoepidemiologic studies. CD shares common mechanisms of antigen presentation and T-cell-mediated immune activation with multiple sclerosis ${ }^{7}$ and rheumatoid arthritis ${ }^{8,9}$ whose geographic distributions show latitudinal association ${ }^{23,24}$. The only study on latitude and CD to our knowledge is from the United States that is located between $20^{\circ}$ and $50^{\circ}$ north and showed a greater prevalence of $C D$ with higher latitudes ${ }^{13}$. A candidate factor typically associated with the latitudinal coordinate that may have a role in causality is vitamin Deffective solar UV radiation. Skin exposure to solar radiation at UVB wavelengths that is determined by the season and latitude is the major source of 25 -hydroxyvitamin $D$ levels in the body in the absence of supplementary intake $\mathrm{e}^{25}$. 26 . Evidence has shown the modulatory effect of vitamin $D$ on the immune system through the inducement and maintenance of tolerogenic immune cells ${ }^{27,28}$. Multiple sclerosis is one of the welldefined autoimmune diseases with latitudinal association and the protective effect of vitamin $D$ in multiple sclerosis has been extensively investigated ${ }^{12,29,30}$. The immunomodulatory effect of vitamin $D$ towards immune tolerance was further supported by the association of incidence and disease activity with vitamin $D$ levels in multiple sclerosis $^{12,30}$, inflammatory bowel diseases ${ }^{31,32}$, rheumatoid arthritis ${ }^{33}$ and systemic lupus erythematosus ${ }^{34}$. Vitamin D deficiency in celiac disease, as a fat soluble vitamin in 
a malabsorptive condition, is common; however, its role in pathogenesis is not known ${ }^{35-}$ 37

Latitude may be a proxy for socioeconomic status or infection with common viruses. Certain environmental pathogens such as enteroviruses ${ }^{38,39}$ and adenoviruses ${ }^{40-42}$ have been shown to be associated with development of $C D^{43}$. Socioeconomic status may result in differences in environmental conditions in complex ways including differential exposure to infections, vaccines, antibiotic use, microbial flora, and gluten consumption, but there are no conclusive data showing an association with socioeconomic status and celiac disease $e^{44-46}$

The gradient effect in rheumatoid arthritis and multiple sclerosis is observed to reverse or diminish in countries located at higher latitudes, such as Norway and Sweden ${ }^{7} 47$. Namatovu et. al. found that childhood CD was more prevalent in the southern latitudes of Sweden than in its northern latitudes and attributed this pattern to differences in awareness and rates of yearly epidemics of viruses ${ }^{48}$. Environmental factors including cultural differences and infections may surpass the effect of latitude associated factors. We did not have finely delineated distributions of prevalence in latitudes above $60^{\circ}$ to examine a similar trend in higher latitudes.

This meta-regression analysis did not show a uniform distribution of latitudinal gradient of CD globally. The disease was prevalent between the latitudes of $20^{\circ}$ and $30^{\circ}$. Located near this area, Saudi Arabia and Brazil have reported prevalence rates comparable to those of Northern Europe. Increased prevalence and younger age at presentation of 
rheumatoid arthritis are also observed in countries near the Northern Tropic $\left(23^{\circ} 26^{\prime} 12.4^{\prime \prime} \text { north of the equator }\right)^{8}$. This outcome was attributed to the developmental status of countries and to related environmental exposures such as infections. Despite having high HLA genotype frequencies and one of the highest rankings in per-capita wheat consumption, Iran had a reported prevalence that was not as high as Saudi Arabia, which is located in a lower latitude, or Western European countries (data from http://www.fao.org, accessed April 24, 2019). The reasons for this trend have yet to be explained.

We estimated the worldwide celiac disease serum prevalence at $0.79 \%$ with substantial variation (95\% Cl: $\left.0.71-0.88 \%, \mathrm{I}^{2}=91 \%\right)$. A previous $\mathrm{CD}$ study estimated a higher global prevalence ${ }^{1}$. Because a sequential testing strategy was shown to be more sensitive and specific ${ }^{49-52}$, we included screening results of sequential testing ${ }^{53}$ or the more specific tTG test assay results rather than AGA or less specific tTG test assays ${ }^{54-}$ ${ }^{56}$, when available. Additionally, we used criteria that specified inclusion of population samples without risk factors. These differences may account for the lower prevalence estimation in our study compared with previous meta-analysis studies of global or regional prevalence ${ }^{1,57}$. The other potential reason may be the overrepresentation of small studies as shown in the funnel plot as smaller studies tended to show lower prevalence estimates ${ }^{58-61}$. This phenomenon could also be due to the aggregation of the larger scale studies in more prevalent areas such as Europe and North America. 


\section{Strengths}

The comprehensive nature of the systematic review of prevalence studies is a major strength of the present study. We included screening year and testing type in our regression analysis to accommodate for known factors associated with prevalence. We included only serum-based screening studies for 2 main reasons. First, CD may be clinically silent, and most cases are undiagnosed. Studies from Northern European regions report increased awareness of CD starting in earlier years ${ }^{62,63}$. Yet, recent studies have showed that a substantial proportion of CD is undiagnosed in parts of the world where people of North African and Middle Eastern descent predominate ${ }^{1}$. Second, screening studies based on biopsy results tend to have low response rates, and it is difficult to standardize the results. Therefore, our analysis reflects disease prevalence that is independent of region-specific differences in awareness of CD. We included studies with sequential testing that included EMA because this test has been shown to have the highest sensitivity and specificity ${ }^{16,17}$. Because sequential or EMA alone testing is more specific than $\lg$ A tTGA results, we controlled for the type of testing in our models.

\section{Limitations}

Our study has some limitations. The latitudes assigned to each location in the present study were not precise. We found considerable heterogeneity between studies. There is a possibility of bias caused by extreme prevalence estimates from small sample studies in higher and lower latitudes. CD is more prevalent in women, but we did not have enough data from all studies to include sex in the analysis. Some regions were not represented in our analysis, including Sub-Saharan Africa and Canada, because either 
no studies were available or met our inclusion criteria. Although HLA-DQ2 and HLADQ8 are known major genetic determinants of $C D$, data for HLA haplotype distributions were too heterogeneous and were not available for most study locations. Moreover, the provided allele frequencies represented different allele haplotypes. Some of the reported HLA allele frequencies were of certain ethnic populations and minority groups, whereas CD prevalence for corresponding locations provided prevalence for Caucasians. Various studies used different commercial test assays with different cutoffs, and we regarded each test result as positive according to the reporting in respective studies. Some prevalence studies used blood donors and convenience sampling methods which may not always be considered representative of general population; however, we evaluated studies systematically for methodological quality including for assessment of representation of the general population. All included studies had low or moderate risk of study bias.

\section{Conclusions}

We found serology-based $C D$ prevalence was greater in higher latitudes away from equator toward south and north, similar to associations observed in chronic autoimmune diseases. Further studies on candidate environmental factors that are latitudeassociated including vitamin-D effective UVB exposure, environmental pathogens, and countries' developmental status will advance the understanding of factors responsible for geographical variation of $C D$ prevalence.

\section{Figure Legend}

Figure 1. Flow Diagram of Identified Studies 
Figure 2. Forest Plot

Figure 3. World map showing the distribution of the studies

Supplemental Material 6. Scatter plot of log-transformed prevalence against latitude and fitted linear prediction. The area of each circle is inversely proportional to the variance of the prevalence of each study location.

Supplemental Material 8. Funnel plot examining publication bias 


\section{References}

1. Singh P, Arora A, Strand TA, et al. Global Prevalence of Celiac Disease: Systematic Review and Meta-analysis. Clin Gastroenterol Hepatol 2018;16:823-836.e2.

2. Jansson-Knodell CL, Hujoel IA, West CP, et al. Sex Difference in Celiac Disease in Undiagnosed Populations: A Systematic Review and Meta-analysis. Clin Gastroenterol Hepatol 2019;17:1954-1968.e13.

3. Rubio-Tapia A, Kyle RA, Kaplan EL, et al. Increased prevalence and mortality in undiagnosed celiac disease. Gastroenterology 2009;137:88-93.

4. Lionetti E, Catassi C. Co-localization of gluten consumption and HLA-DQ2 and -DQ8 genotypes, a clue to the history of celiac disease. Dig Liver Dis 2014;46:1057-63.

5. Ramakrishna BS, Makharia GK, Chetri K, et al. Prevalence of Adult Celiac Disease in India: Regional Variations and Associations. Am J Gastroenterol 2016;111:115-23.

6. Abadie V, Sollid LM, Barreiro LB, et al. Integration of Genetic and Immunological Insights into a Model of Celiac Disease Pathogenesis. Annual Review of Immunology 2011;29:493-525.

7. Simpson S, Jr., Blizzard L, Otahal $P$, et al. Latitude is significantly associated with the prevalence of multiple sclerosis: a meta-analysis. J Neurol Neurosurg Psychiatry 2011;82:1132-41.

8. Latitude gradient influences the age of onset of rheumatoid arthritis: a worldwide survey. Clin Rheumatol 2017;36:485-497.

9. Vieira VM, Hart JE, Webster TF, et al. Association between residences in U.S. northern latitudes and rheumatoid arthritis: A spatial analysis of the Nurses' Health Study. Environ Health Perspect 2010;118:957-61.

10. Khalili $\mathrm{H}$, Huang ES, Ananthakrishnan AN, et al. Geographical variation and incidence of inflammatory bowel disease among US women. Gut 2012;61:1686-92.

11. Hong Q, Xu J, Xu S, et al. Associations between serum 25-hydroxyvitamin D and disease activity, inflammatory cytokines and bone loss in patients with rheumatoid arthritis. Rheumatology (Oxford) 2014;53:1994-2001.

12. Nieves J, Cosman F, Herbert J, et al. High prevalence of vitamin D deficiency and reduced bone mass in multiple sclerosis. Neurology 1994;44:1687-92.

13. Unalp-Arida A, Ruhl CE, Choung RS, et al. Lower Prevalence of Celiac Disease and Gluten-Related Disorders in Persons Living in Southern vs Northern Latitudes of the United States. Gastroenterology 2017;152:1922-1932.e2.

14. Moher D, Liberati A, Tetzlaff J, et al. Preferred Reporting Items for Systematic Reviews and Meta-Analyses: The PRISMA Statement. Journal of Clinical Epidemiology 2009;62:1006-1012.

15. Aniwan S, Harmsen WS, Tremaine WJ, et al. Overall and Cause-Specific Mortality of Inflammatory Bowel Disease in Olmsted County, Minnesota, From 1970 Through 2016. Mayo Clin Proc 2018;93:1415-1422.

16. Husby S, Koletzko S, Korponay-Szabo IR, et al. European Society for Pediatric Gastroenterology, Hepatology, and Nutrition guidelines for the diagnosis of coeliac disease. J Pediatr Gastroenterol Nutr 2012;54:136-60.

17. Husby S, Murray JA, Katzka DA. AGA Clinical Practice Update on Diagnosis and Monitoring of Celiac Disease-Changing Utility of Serology and Histologic Measures: Expert Review. Gastroenterology 2019;156:885-889.

18. Hoy $D$, Brooks $P$, Woolf $A$, et al. Assessing risk of bias in prevalence studies: modification of an existing tool and evidence of interrater agreement. J Clin Epidemiol 2012;65:934-9. 
19. Nyaga VN, Arbyn M, Aerts M. Metaprop: a Stata command to perform meta-analysis of binomial data. Arch Public Health 2014;72:39.

20. Higgins JP, Thompson SG. Quantifying heterogeneity in a meta-analysis. Stat Med 2002;21:1539-58.

21. Thompson SG, Sharp SJ. Explaining heterogeneity in meta-analysis: a comparison of methods. Stat Med 1999;18:2693-708.

22. Egger M, Davey Smith G, Schneider M, et al. Bias in meta-analysis detected by a simple, graphical test. Bmj 1997;315:629-34.

23. Lindfors K, Ciacci C, Kurppa K, et al. Coeliac disease. Nat Rev Dis Primers 2019;5:3.

24. Zhernakova A, Stahl EA, Trynka G, et al. Meta-analysis of genome-wide association studies in celiac disease and rheumatoid arthritis identifies fourteen non-HLA shared loci. PLoS Genet 2011;7:e1002004.

25. Holick MF. Vitamin D: importance in the prevention of cancers, type 1 diabetes, heart disease, and osteoporosis. The American Journal of Clinical Nutrition 2004;79:362-371.

26. Webb AR, Kline L, Holick MF. Influence of Season and Latitude on the Cutaneous Synthesis of Vitamin D3: Exposure to Winter Sunlight in Boston and Edmonton Will Not Promote Vitamin D3Synthesis in Human Skin*. The Journal of Clinical Endocrinology \& Metabolism 1988;67:373-378.

27. Booth DR, Ding N, Parnell GP, et al. Cistromic and genetic evidence that the vitamin D receptor mediates susceptibility to latitude-dependent autoimmune diseases. Genes Immun 2016;17:213-9.

28. Nagy L, Szanto A, Szatmari I, et al. Nuclear Hormone Receptors Enable Macrophages and Dendritic Cells to Sense Their Lipid Environment and Shape Their Immune Response. Physiological Reviews 2012;92:739-789.

29. Ascherio A, Munger KL, Simon KC. Vitamin D and multiple sclerosis. The Lancet Neurology 2010;9:599-612.

30. Munger KL, Levin LI, Hollis BW, et al. Serum 25-Hydroxyvitamin D Levels and Risk of Multiple Sclerosis. JAMA 2006;296:2832.

31. Del Pinto R, Pietropaoli D, Chandar AK, et al. Association Between Inflammatory Bowel Disease and Vitamin D Deficiency. Inflammatory Bowel Diseases 2015;21:2708-2717.

32. Ananthakrishnan AN, Khalili H, Higuchi LM, et al. Higher Predicted Vitamin D Status Is Associated With Reduced Risk of Crohn's Disease. Gastroenterology 2012;142:482-489.

33. Hong Q, Xu J, Xu S, et al. Associations between serum 25-hydroxyvitamin D and disease activity, inflammatory cytokines and bone loss in patients with rheumatoid arthritis. 2014;53:1994-2001.

34. Mok CC. Vitamin D and systemic lupus erythematosus: an update. Expert Rev Clin Immunol 2013;9:453-63.

35. Tavakkoli A, DiGiacomo D, Green PH, et al. Vitamin D status and concomitant autoimmunity in celiac disease. J Clin Gastroenterol 2013;47:515-9.

36. Schosler L, Christensen LA, Hvas CL. Symptoms and findings in adult-onset celiac disease in a historical Danish patient cohort. Scand J Gastroenterol 2016;51:288-94.

37. Ciacci C, Bilancio G, Russo I, et al. 25-Hydroxyvitamin D, 1,25-Dihydroxyvitamin D, and Peripheral Bone Densitometry in Adults with Celiac Disease. Nutrients 2020;12:929.

38. Kahrs CR, Chuda K, Tapia G, et al. Enterovirus as trigger of coeliac disease: nested case-control study within prospective birth cohort. Bmj 2019;364:I231.

39. Stene LC, Honeyman MC, Hoffenberg EJ, et al. Rotavirus infection frequency and risk of celiac disease autoimmunity in early childhood: a longitudinal study. Am J Gastroenterol 2006;101:2333-40.

40. Bouziat R, Hinterleitner R, Brown JJ, et al. Reovirus infection triggers inflammatory responses to dietary antigens and development of celiac disease. Science 2017;356:4450. 
41. Kagnoff MF, Paterson YJ, Kumar PJ, et al. Evidence for the role of a human intestinal adenovirus in the pathogenesis of coeliac disease. Gut 1987;28:995-1001.

42. Lähdeaho ML, Parkkonen P, Reunala T, et al. Antibodies to E1b Protein-Derived Peptides:of Enteric Adenovirus Type 40 Are Associated with Celiac Disease and Dermatitis Herpetiformis. Clinical Immunology and Immunopathology 1993;69:300-305.

43. Plot L, Amital H. Infectious associations of Celiac disease. Autoimmunity Reviews 2009;8:316-319.

44. Kondrashova A, Mustalahti K, Kaukinen K, et al. Lower economic status and inferior hygienic environment may protect against celiac disease. Ann Med 2008;40:223-31.

45. Olen O, Bihagen E, Rasmussen F, et al. Socioeconomic position and education in patients with coeliac disease. Dig Liver Dis 2012;44:471-6.

46. Wingren CJ, Bjorck S, Lynch KF, et al. Coeliac disease in children: a social epidemiological study in Sweden. Acta Paediatr 2012;101:185-91.

47. Kampman MT, Brustad M. Vitamin D: a candidate for the environmental effect in multiple sclerosis - observations from Norway. Neuroepidemiology 2008;30:140-6.

48. Namatovu F, Lindkvist M, Olsson C, et al. Season and region of birth as risk factors for coeliac disease a key to the aetiology? Archives of Disease in Childhood 2016;101:1114-1118.

49. Kumar V, Lerner A, Valeski JE, et al. Endomysial antibodies in the diagnosis of celiac disease and the effect of gluten on antibody titers. Immunol Invest 1989;18:533-44.

50. Murray JA, Herlein J, Mitros F, et al. Serologic testing for celiac disease in the United States: results of a multilaboratory comparison study. Clin Diagn Lab Immunol 2000;7:584-7.

51. Walker MM, Murray JA, Ronkainen J, et al. Detection of Celiac Disease and Lymphocytic Enteropathy by Parallel Serology and Histopathology in a PopulationBased Study. Gastroenterology 2010;139:112-119.

52. Katz KD, Rashtak S, Lahr BD, et al. Screening for celiac disease in a North American population: sequential serology and gastrointestinal symptoms. Am J Gastroenterol 2011;106:1333-9.

53. Trevisiol C, Not T, Berti I, et al. Screening for coeliac disease in healthy blood donors at two immuno-transfusion centres in north-east Italy. Italian Journal of Gastroenterology \& Hepatology 1999;31:584-6.

54. Ramakrishna BS, Makharia GK, Chetri K, et al. Prevalence of Adult Celiac Disease in India: Regional Variations and Associations. American Journal of Gastroenterology 2016;111:115-23.

55. Vancikova Z, Chlumecky V, Sokol D, et al. The serologic screening for celiac disease in the general population (blood donors) and in some high-risk groups of adults (patients with autoimmune diseases, osteoporosis and infertility) in the Czech republic. Folia Microbiologica 2002;47:753-8.

56. Zintzaras E, Germenis AE. Performance of antibodies against tissue transglutaminase for the diagnosis of celiac disease: meta-analysis. Clin Vaccine Immunol 2006;13:18792.

57. Parra-Medina R, Molano-Gonzalez N, Rojas-Villarraga A, et al. Prevalence of celiac disease in latin america: a systematic review and meta-regression. PLoS One 2015;10:e0124040.

58. Fukunaga M, Ishimura N, Fukuyama $\mathrm{C}$, et al. Celiac disease in non-clinical populations of Japan. Journal of Gastroenterology 2017;07:07.

59. Karagiozoglou-Lampoudi T, Zellos A, Vlahavas G, et al. Screening for coeliac disease in preschool Greek children: the feasibility study of a community-based project. Acta Paediatrica 2013;102:749-54. 
60. Metskula K, Grunberg H, Uibo O, et al. Antigliadin antibodies and autoantibodies among 9, 12 and 15 year-old schoolchildren. Central-European Journal of Immunology 1998;23:197-202.

61. Utiyama SRdR, Ribas JLC, Nisihara RM, et al. Celiac disease in native Indians from Brazil: A clinical and epidemiological survey. North American Journal of Medical Sciences 2010;2:138-42.

62. Steens RF, Csizmadia CG, George EK, et al. A national prospective study on childhood celiac disease in the Netherlands 1993-2000: an increasing recognition and a changing clinical picture. J Pediatr 2005;147:239-43.

63. Dominguez Castro P, Harkin G, Hussey M, et al. Changes in Presentation of Celiac Disease in Ireland From the 1960s to 2015. Clin Gastroenterol Hepatol 2017;15:864871.e3. 


\section{Supplemental Material. Results of Univariate and Multivariate Random-Effects Regression ${ }^{a}$}

\begin{tabular}{|c|c|c|}
\hline Variable & Relative Risk (95\% Cl) & $P$ Value \\
\hline \multicolumn{3}{|c|}{ Unadjusted } \\
\hline Latitude & $1.01(1.00-1.02)$ & 0.071 \\
\hline \multicolumn{3}{|c|}{ Multivariate regression without regions ${ }^{b}$} \\
\hline Latitude & $1.02(1.00-1.03)$ & 0.009 \\
\hline Pediatric age group $^{d}$ & $1.44(1.07-1.94)$ & 0.018 \\
\hline Testing method, tTG $^{\mathrm{e}}$ & $1.59(1.10-2.32)$ & 0.015 \\
\hline Screening year & $1.01(0.99-1.04)$ & 0.356 \\
\hline \multicolumn{3}{|c|}{ Multivariate regression with regions ${ }^{c}$} \\
\hline Latitude & $1.03(1.01-1.05)$ & 0.014 \\
\hline Pediatric age group $^{d}$ & $1.42(1.03-1.96)$ & 0.032 \\
\hline Testing method $^{\mathrm{e}}$ & $1.53(1.03-2.27)$ & 0.034 \\
\hline Screening year & $1.02(0.99-1.04)$ & 0.228 \\
\hline Europe (reference) & 1 & \\
\hline North Africa and Middle East & $1.541(0.88-2.70)$ & 0.228 \\
\hline Latin America and the Caribbean & $1.44(0.61-3.42)$ & 0.407 \\
\hline Australia and New Zealand & $2.40(0.84-6.88)$ & 0.101 \\
\hline East and South Asia & $0.90(0.33-2.47)$ & 0.831 \\
\hline North America & $0.96(0.51-1.81)$ & 0.909 \\
\hline
\end{tabular}

${ }^{a}$ Model includes log-transformed prevalence estimates as the dependent variable.

${ }^{\mathrm{b}}$ Model includes covariates of latitude, age group, screening year, and testing method.

${ }^{\mathrm{C}}$ Model includes covariates of latitude, age group, screening year, test type, and world regions.

${ }^{\mathrm{d}}$ Adult age group as reference

${ }^{\mathrm{e}}$ Sequential testing as reference 
Table 1. Prevalence Estimates for Individual Regions and Latitudinal Intervals

\begin{tabular}{|c|c|c|c|}
\hline Value & $\begin{array}{l}\text { No. of Cohorts (No. } \\
\text { of Studies) }\end{array}$ & $\begin{array}{l}\text { Pooled Prevalence } \\
\text { Estimate } \%(95 \% \mathrm{Cl})\end{array}$ & $r^{2}, \%$ \\
\hline World pooled estimate & $155(127)$ & $0.79(0.71-0.88)$ & 91.2 \\
\hline \multicolumn{4}{|l|}{ World region } \\
\hline North Africa and Middle East & $30(27)$ & $0.96(0.74-1.23)$ & 89.6 \\
\hline Latin America and the Caribbean & $13(13)$ & $0.51(0.3-0.88)$ & 89.8 \\
\hline Australia and New Zealand & $3(3)$ & $1.27(1.02-1.57)$ & NA \\
\hline Europe & $91(73)$ & $0.83(0.72-0.95)$ & 90.4 \\
\hline East and South Asia & $7(5)$ & $0.45(0.24-0.86)$ & 94.9 \\
\hline North America & $11(6)$ & $0.57(0.37-0.88)$ & 95.1 \\
\hline \multicolumn{4}{|l|}{ Latitudinal interval } \\
\hline$\leq 20^{\circ}$ & $9(9)$ & $0.55(0.02-1.27)$ & 92.9 \\
\hline$>20^{\circ}$ to $\leq 30^{\circ}$ & $19(17)$ & $0.98(0.7-1.36)$ & 90.9 \\
\hline$>30^{\circ}$ to $\leq 40^{\circ}$ & $34(30)$ & $0.58(0.44-0.78)$ & 92 \\
\hline$>40^{\circ}$ to $\leq 50^{\circ}$ & $42(36)$ & $0.67(0.55-0.81)$ & 90 \\
\hline$>50^{\circ}$ to $\leq 60^{\circ}$ & $37(31)$ & $0.99(0.81-1.22)$ & 90.8 \\
\hline$>60^{\circ}$ to $\leq 70^{\circ}$ & $14(13)$ & $1.24(0.99-1.54)$ & 83.4 \\
\hline
\end{tabular}

Abbreviation: NA, not available.

Table 2. Adjusted Relative Risk for Latitudinal Intervals

\begin{tabular}{|c|c|c|}
\hline Latitudinal Intervals & No. of Cohorts & Relative Risk (95\% Cl) \\
\hline$\leq 20^{\circ}$ & 9 & $0.87(0.29-2.66)$ \\
\hline$>20^{\circ}$ to $\leq 30^{\circ}$ & 19 & $0.95(0.37-2.40)$ \\
\hline$>30^{\circ}$ to $\leq 40^{\circ}$ & 34 & $0.50(0.25-1.02)$ \\
\hline$>40^{\circ}$ to $\leq 50^{\circ}$ & 42 & 1.0 (reference) \\
\hline$>50^{\circ}$ to $\leq 60^{\circ}$ & 37 & $1.62(1.09-2.38)^{a}$ \\
\hline$>60^{\circ}$ to $\leq 70^{\circ}$ & 14 & $2.30(1.36-3.89)^{a}$ \\
\hline
\end{tabular}

${ }^{a}$ Bold indicates statistical significance.

Model includes covariates of age group, screening year, test type, and world regions, with logtransformed prevalence estimates as the dependent variable.

Table 3. Region-Specific and Global Latitudinal Coefficients ${ }^{a}$

\begin{tabular}{|l|l|l|}
\hline Region & Relative Risk (95\% Cl) & $\boldsymbol{P}$ Value \\
\hline World $^{\mathrm{a}}$ & $1.03(1.01-1.05)$ & .014 \\
\hline Europe $^{\mathrm{b}}$ & $1.05(1.02-1.07)$ & $<.001$ \\
\hline North America $^{\mathrm{b}}$ & $1.10(1.00-1.20)$ & .05 \\
\hline North Africa and Middle East $^{\mathrm{b}}$ & $1.00(0.90-1.01)$ & .11 \\
\hline Latin America and the Caribbean $^{\mathrm{b}}$ & $1.01(0.93-1.10)$ & .41 \\
\hline East and South Asia $^{\mathrm{b}}$ & $0.88(0.59-1.30)$ & .36 \\
\hline
\end{tabular}


a Model includes covariates of age group, screening year, test type, and world regions, with logtransformed prevalence estimates as the dependent variable.

${ }^{\mathrm{b}}$ Model includes covariates of age group, screening year, and testing method. 
Figure 1. Flow Diagram of Identified Studies

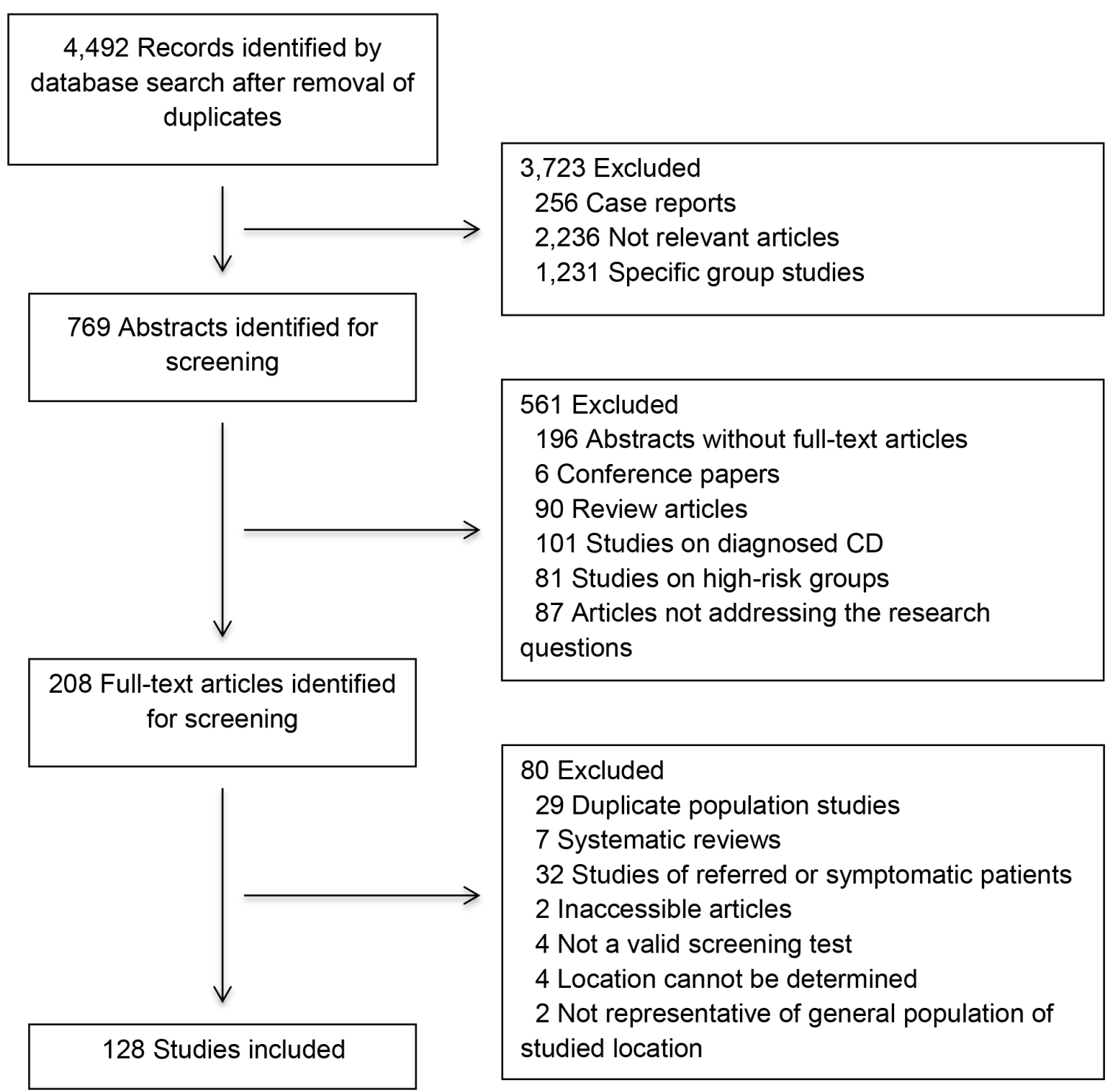




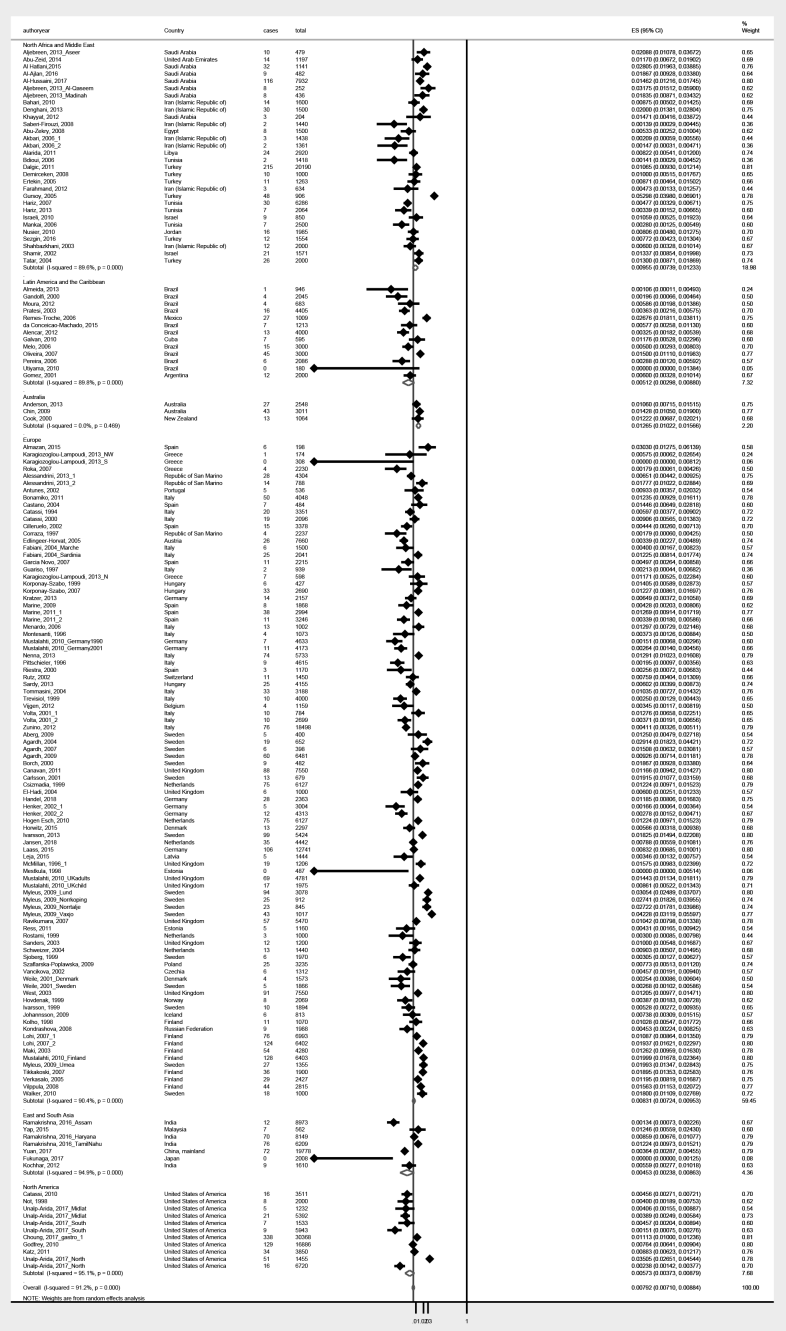




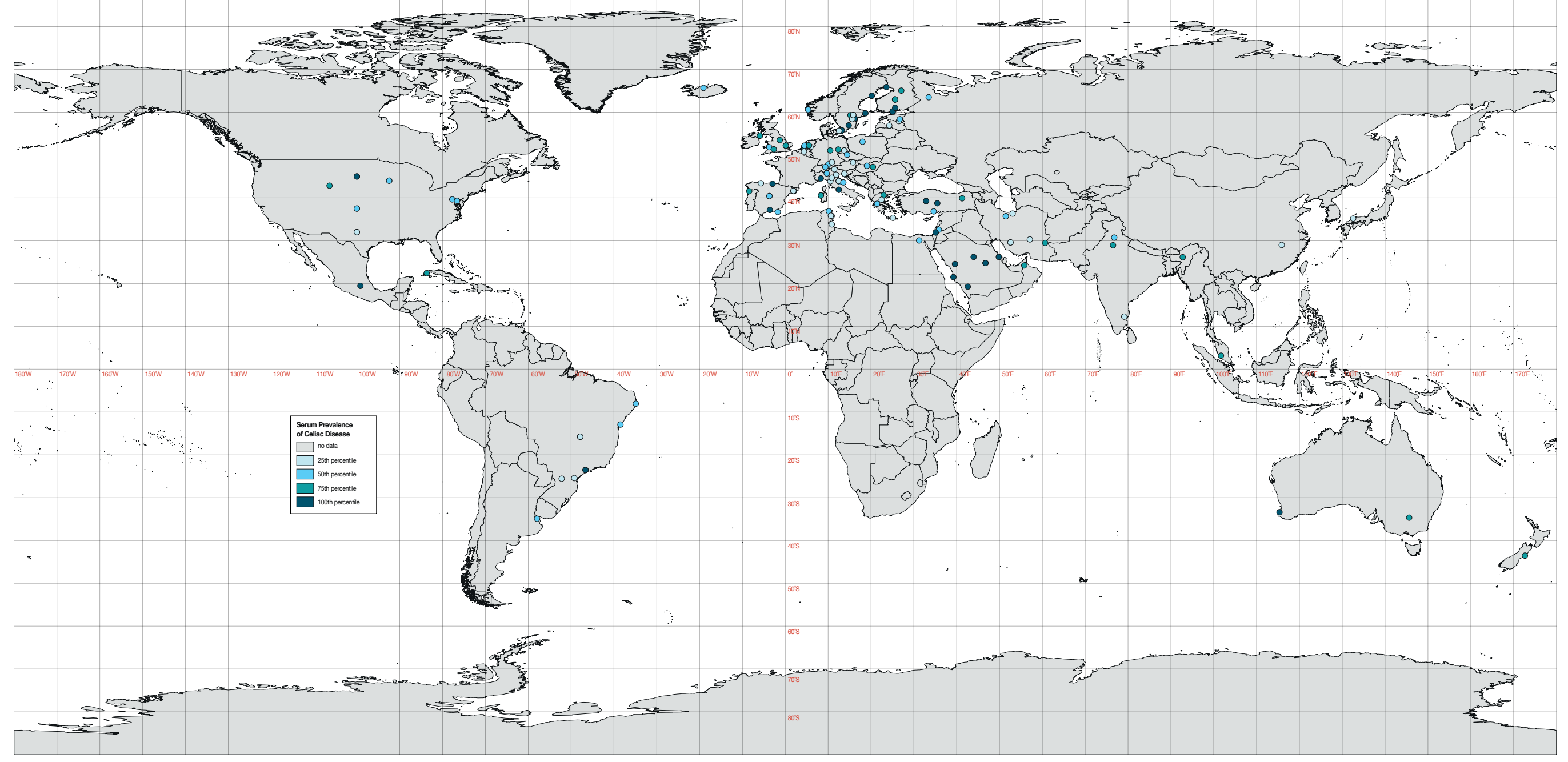




\section{Supplemental Material 2. Characteristics of Included Studies}

\begin{tabular}{|c|c|c|c|c|c|c|c|c|c|c|c|c|}
\hline Study & $\begin{array}{l}\begin{array}{l}\text { Year of } \\
\text { screeni } \\
\text { ng }\end{array} \\
\text { S }\end{array}$ & country & City/Province & Latitude & Age,, & Population & $\begin{array}{c}\text { Convenience } \\
\text { Sampling Details }\end{array}$ & $\begin{array}{c}\text { Screening } \\
\text { Test }\end{array}$ & $\begin{array}{c}\text { Confirm } \\
\text { atory } \\
\text { Test }\end{array}$ & No. Screened & $\begin{array}{l}\text { No. of } \\
\text { Cases }\end{array}$ & $\begin{array}{c}\text { Proportion of } \\
\text { Cases }\end{array}$ \\
\hline Aberg, $2009^{1}$ & 2008 & Sweden & Orebro & 59.30 & 20.99 & Blood donors & & tTGA & EMA & 400 & 5 & 0.0125 \\
\hline Abu-Zeid, $2014^{2}$ & & UAE & Al Ain & 24.21 & & Converience sampling & $\begin{array}{l}\text { Prenuptial } \\
\text { examination }\end{array}$ & tTGA & EMA & 1197 & 14 & \\
\hline Abu-Zekry, $2008^{3}$ & 2004 & Egypt & Cairo & 30.05 & 0.18 & Convenience sampling & General outpatient & tTGA & EMA & 1500 & 16 & 0.0053 \\
\hline Agardh, $2004^{4}$ & 2000 & Sweden & Malmo & 55.61 & $2-4$ & General population & & tTGA & EMA & 652 & 19 & 0.0291 \\
\hline Agardh, $2007^{5}$ & 2007 & Sweden & Malmo & 55.61 & 19.81 & General population & & $\operatorname{tTGA}$ & $\mathrm{NA}$ & 398 & & 0.0151 \\
\hline Agardh, $2009^{6}$ & 2000 & Sweden & Lund & 55.78 & 50:64 & General population & Female patients & $\operatorname{tTtGA}$ & $\mathrm{NA}$ & 6481 & 60 & 0.0093 \\
\hline Akbari, 2006__1 & 2004 & Iran & Sari & 36.33 & $\begin{array}{l}18 \cdot 66 \\
-66\end{array}$ & General population & & tTGA & EMA & 1438 & 3 & 0.0021 \\
\hline 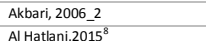 & 2004 & Iran & Kerman & 30.29 & $18-66$ & General population & & tTGA & EMA & 1361 & 2 & 0.0015 \\
\hline Al Hattani,2015 & & & $\begin{array}{l}\text { EEstern rivoince, } \\
\text { National Guard }\end{array}$ & & 6-18 & General population & & tTGA & $\mathrm{NA}$ & 1141 & 32 & 0.0280 \\
\hline Al-Ailan, 2016 & 2013 & Saudi Arabia & Rivadh & 24.77 & 20.60 & General population & & $\operatorname{tTGA}$ & EMA & 482 & 9 & 0.0187 \\
\hline Alarida, $2011^{10}$ & 2011 & Libya & El|Beida & 36.7 & 5-17 & General population & & tTGA & $\mathrm{NA}$ & 2920 & 24 & 0.0146 \\
\hline 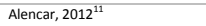 & 2004 & Brazil & San Paulo & 23.55 & $18-65$ & Blood donors & & $\operatorname{tTGA}$ & EMA & 4000 & 14 & 0.0082 \\
\hline Alessandrini, 2013_1 $1^{12}$ & 2005 & $\begin{array}{l}\text { Republic of San } \\
\text { Marino }\end{array}$ & $\begin{array}{l}\text { Republic of San } \\
\text { Marino }\end{array}$ & 43.94 & $6 \cdot 14$ & General population & & AGA & EMA & 4304 & 28 & 0.0033 \\
\hline Alessandrini, 2013_2 & 2009 & $\begin{array}{l}\text { Republic of San } \\
\text { Marino }\end{array}$ & $\begin{array}{l}\text { Republic of fan } \\
\text { Marino }\end{array}$ & 43.94 & 6-10 & General population & & tTGA & EMA & 788 & 14 & 0.0065 \\
\hline Al-Hussaini, $2017^{13}$ & 2016 & Saudi Arabia & Rivadh & 24.8 & $6 \cdot 15$ & General population & & tTGA & EMA & 7932 & 116 & 0.0178 \\
\hline Aljebreen, 2013_Al-Qaseem m $^{14}$ & 2008 & Saudi Arabia & At-assem & 26.2 & $16-18$ & General population & & EMA & NA & 252 & 8 & 0.0317 \\
\hline Aljebreen, 2013_Aseer & 2008 & Saudi Arabia & Aseer & 19.26 & $16-18$ & General population & & EMA & $\mathrm{NA}$ & 479 & 10 & 0.0209 \\
\hline Aljebreen, 2013_Madinah & 2008 & Saudi Arabia & Madinah & 24.55 & 16-18 & General population & & EMA & NA & 436 & 8 & 0.0183 \\
\hline Almazan, $2015^{5^{3}}$ & 2012 & Spain & Granada & 37.18 & $2 \cdot 4$ & General population & & tTGA & $\mathrm{NA}$ & 198 & 6 & 0.0303 \\
\hline Almeida, $2013^{16}$ & 2011 & Brazil & 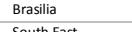 & 15.77 & 60.92 & General population & & tTGA & EMA & ${ }^{946}$ & 1 & 0.0011 \\
\hline Anderson, $2013^{17}$ & 2006 & Australia & 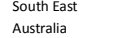 & 34.66 & 20-97 & General population & & tTGA & EMA & 2548 & 27 & 0.0106 \\
\hline Antunes, $2002^{18}$ & 1999 & Portugal & Braga & 41.55 & $13-15$ & General population & & tTGA & EMA & 536 & 5 & 0.0093 \\
\hline Bahari, 2010 & 2007 & Iran & $\begin{array}{l}\text { Sistan and } \\
\text { Baluchentan } \\
\text { Provincee }\end{array}$ & 29.47 & $17-65$ & Blood donors & & tTGA & $\mathrm{NA}$ & 1600 & 14 & 0.0088 \\
\hline Bdioui, $2006^{20}$ & 2004 & Tunisia & Monastir & 35.77 & 17.57 & Blood donors & & EMA & tTGA & 1418 & 2 & 0.0014 \\
\hline Bonamiko, 2011 & 2007 & Italy & Rome & $\begin{array}{r}41.9 \\
58.91\end{array}$ & 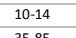 & General population & & tTGA & EMA & 4048 & 50 & 0.0124 \\
\hline Borch, $2000^{22}$ & 2000 & Sweden & Linkoping & 58.41 & $35-85$ & General population & & EMA & $\mathrm{NA}$ & 482 & 9 & 0.0187 \\
\hline Canavan, $2011^{33}$ & 2001 & uK & Cambridge & 52.21 & 45.76 & General population & & EMA & tTGA & 7550 & 88 & 0.0117 \\
\hline $\begin{array}{l}\text { Carlsson, 2001.14 } \\
\text { Castano } 2004^{35}\end{array}$ & 1997 & Sweden & Malmo & 55.61 & $2 \cdot 4$ & General population & & AGA & EMA & 679 & 13 & 0.0191 \\
\hline $\begin{array}{l}\text { Castano, } 2004^{45} \\
\text { Catastisi } 194^{8}\end{array}$ & $\begin{array}{l}2002 \\
1993 \\
\end{array}$ & $\begin{array}{l}\text { Spain } \\
\text { Italy }\end{array}$ & $\begin{array}{l}\text { Bizkaia, Cruces } \\
\text { Pascruthina }\end{array}$ & 43.29 & $<3$ & General population & & tTGA & EMA & $\begin{array}{r}484 \\
3351 \\
3.3510\end{array}$ & 7 & 0.0145 \\
\hline 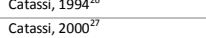 & ${ }_{1993}^{1998} \mathrm{Vl}$ l & $\begin{array}{l}\text { Italy } \\
\text { Italy } \\
\text { and }\end{array}$ & $\begin{array}{l}\text { Pesarorourbino } \\
\text { Aghero }\end{array}$ & $\begin{array}{l}{ }^{43.74} \\
40.56 \\
\end{array}$ & $\begin{array}{l}11.15 \\
11-15\end{array}$ & $\begin{array}{l}\text { Generar population } \\
\text { General population }\end{array}$ & & $\begin{array}{l}A G A \\
A G A\end{array}$ & $\begin{array}{l}\text { EMA } \\
\text { EMA }\end{array}$ & $\begin{array}{l}3351 \\
2096\end{array}$ & ${ }_{19}^{20}$ & $\begin{array}{l}0.0000 \\
0.0091\end{array}$ \\
\hline Catassi, 2010 & 1989 & USA & $\begin{array}{l}\text { Washington } \\
\text { county, Maryland }\end{array}$ & 39.63 & $\begin{array}{l}35-65 \\
35\end{array}$ & General population & & tTGA & EMA & 3511 & 16 & 0.0046 \\
\hline Chin, $2009^{29}$ & 1995 & Australia & Bussetton & 33.39 & $20-79$ & General population & & $\operatorname{tTGA}$ & $\mathrm{NA}$ & 3011 & 43 & 0.0143 \\
\hline Choung, 201770 & 2011 & USA & Olmsted County & 44.02 & 18.50 & $\begin{array}{l}\text { General populution } \\
\text { Ge }\end{array}$ & & tTTA & EMA & 30225 & 372 & 0.0111 \\
\hline Cilleruelo, $2002^{31}$ & 2000 & Spain & Madrid & 40.42 & $10 \cdot 12$ & General population & & EMA & $\mathrm{NA}$ & 3378 & 15 & 0.0044 \\
\hline $\mathrm{Cook}_{,} 2000^{32}$ & 2000 & New Zealand & Christchurch & 43.53 & $>18$ & General population & & EMA & $\mathrm{NA}$ & 1064 & 13 & 0.0122 \\
\hline Corraza, $1997^{7^{3}}$ & 1997 & $\begin{array}{l}\text { Rewublicious can } \\
\text { Marico }\end{array}$ & 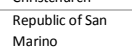 & 43.94 & 18.87 & General population & & EMA & NA & 2237 & 4 & 0.0018 \\
\hline Csizmadia, 1999 ${ }^{34}$ & 1997 & The Netherlands & Zuid-Holland & 51.99 & 2.4 & General population & & EMA & NA & 6127 & 75 & 0.0122 \\
\hline da Conceicao-Machado, $2015^{35}$ & 2009 & Brazil & $\begin{array}{l}\text { Salvador City, } \\
\text { Bahia }\end{array}$ & 12.93 & 11-17 & General population & & tTGA & NA & 1213 & 7 & 0.0058 \\
\hline Dalgic, $2011^{36}$ & 2008 & Turkey & Turkey & 39.25 & 6-17 & General population & & $\operatorname{tTGA}$ & EMA & 20190 & 215 & 0.0106 \\
\hline Demirceken, $2008^{37}$ & 2003 & Turkey & Ankara & 39.56 & $2 \cdot 18$ & Convenience sampling & $\begin{array}{l}\text { General outpatient } \\
\text { clinic }\end{array}$ & tTGA & EMA & 1000 & 10 & 0.0100 \\
\hline 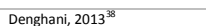 & 2013 & Iran & Shiraz & 29.59 & $6 \cdot 12$ & General population & & tTGA & NA & 1500 & 30 & 0.0200 \\
\hline Edlingeer-Horvat, $2005^{90}$ & 2002 & Austria & Lower Austria & 48.3 & $17-18$ & Convenience sampling & $\begin{array}{l}\text { Compulsory } \\
\text { conscript medical } \\
\text { examination, all } \\
\text { males }\end{array}$ & TTGA & EMA & 7660 & 26 & 0.0034 \\
\hline 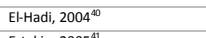 & 2002 & uK & Wales & 51.83 & $18-22$ & General population & & tTGA & EMA & 1000 & 6 & 0.0060 \\
\hline Ertekin, $2005^{4 a}$ & & Turkey & Errurum & & & General population & & & NA & 1263 & 11 & 0.0087 \\
\hline
\end{tabular}




\begin{tabular}{|c|c|c|c|c|c|c|c|c|c|c|c|c|}
\hline Fabiani, 2004_Marche ${ }^{12}$ & 2001 & Italy & Camerano, Marche & 43.61 & 1.91 & General population & & tTGA & EMA & 1500 & 6 & 0.0040 \\
\hline Fabiani, 2004_Sardinia & 2001 & Italy & Alghero, Sardinia & 40.56 & 10-19 & General population & & tTGA & EMA & 2041 & 25 & \\
\hline Farahmand, $2012^{2^{38}}$ & 2008 & Iran & Tehran & 35.7 & $7 \cdot 18$ & General population & & tTGA & $\mathrm{NA}$ & 634 & & 0.0047 \\
\hline Fuknagaga, 2017" & 2016 & Japan & Shimane & 35.16 & $25-80$ & General population & & tTGA & EMA & 2008 & 0 & 0.0000 \\
\hline Galvan, $2010^{30}$ & 2007 & Cuba & Pinar del Rio & 22.42 & 3 & General population & & tTGA & NA & 595 & 7 & 0.0118 \\
\hline Gandofit, 2000 & 1998 & Brazil & Braslilia & 15.77 & 18-61 & Blood donors & & AGA & EMA & 2045 & 4 & 0.0020 \\
\hline $\begin{array}{l}\text { Gacla Novo, } 2007 \\
\text { Godrey } 210^{48}\end{array}$ & 2002 & $\begin{array}{l}\text { Spainn } \\
\text { Sals }\end{array}$ & Madrocid & 40.42 42 & 18.65 & Generata poppuation & & tTGA & $\mathrm{NA}$ & 22215 & 11 & 0.0050 \\
\hline 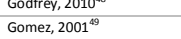 & $\begin{array}{l}2001 \\
2000\end{array}$ & USA & $\begin{array}{l}\text { Omimsted County } \\
\text { La Plata, Buenos }\end{array}$ & $\begin{array}{l}44.422 \\
34.92\end{array}$ & $\begin{array}{l}50.88 \\
16-79\end{array}$ & $\begin{array}{l}\text { Generar popplation } \\
\text { General population }\end{array}$ & & $\begin{array}{l}\text { tiGA } \\
\text { AGA }\end{array}$ & $\begin{array}{l}\text { EMA } \\
\text { EMA }\end{array}$ & 20800 & 129 & $\begin{array}{l}0.0076 \\
0.0060\end{array}$ \\
\hline Guariso, $1999^{7^{\circ}}$ & 1995 & Italy & $\begin{array}{l}\text { Aires } \\
\text { Padua }\end{array}$ & 45.4 & $10-15$ & General population & & AGA & EMA & 939 & 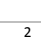 & 0.0021 \\
\hline Gursoy, 2005年 & 2004 & Turkey & Kayseri & 38.73 & 20.59 & Conveniences sampling & $\begin{array}{l}\text { Routine examination } \\
\text { for general medical }\end{array}$ & tTGA & $\mathrm{NA}$ & 906 & 48 & 0.0530 \\
\hline Hande, $2018^{5^{2}}$ & 2015 & Germany & Leipzig & 51.3 & $1-18$ & General population & & tTGA & EMA & 2363 & 28 & 0.0118 \\
\hline Harí, $200^{73}$ & 2004 & Tunisia & Ariana & 36.86 & $7 \cdot 13$ & General population & & tTGA & EMA & 6286 & ${ }_{30}$ & 0.0048 \\
\hline Hariz, $2013^{54}$ & 2011 & Tunisia & Djerba & 33.81 & 6-12 & General population & & tTGA & EMA & 2064 & 7 & 0.0034 \\
\hline 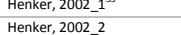 & 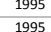 & $\begin{array}{l}\text { Gerrmany } \\
\text { Germany }\end{array}$ & $\begin{array}{l}\text { Dressen } \\
\text { Dersden }\end{array}$ & 51.07 & 5-12 & General population & & EMA & NA & 3004 & 5 & 0.0017 \\
\hline Hogen Esch, $2010^{56}$ & 19998 & $\begin{array}{l}\text { Germany } \\
\text { The Netherlands }\end{array}$ & $\begin{array}{l}\text { Doesdan } \\
\text { The Netherlands }\end{array}$ & $\begin{array}{l}5.1 .9 \\
52.24\end{array}$ & $\begin{array}{l}17-64 \\
2-4\end{array}$ & $\begin{array}{l}\text { Bolod donorors } \\
\text { General population }\end{array}$ & & $\begin{array}{l}\text { EMA } \\
\text { EMA }\end{array}$ & NA & 6 & 75 & $\begin{array}{l}0.0028 \\
0.0122\end{array}$ \\
\hline Horwitz, 2015 & 2012 & Denmark & $\begin{array}{l}\text { Southwestern } \\
\text { Copenhagen }\end{array}$ & 55.66 & $24-76$ & General population & & tTGA & NA & 2297 & 13 & 0.0057 \\
\hline Hovdenak, $1999^{88}$ & 1999 & Norway & Bergen & 60.58 & $18-67$ & Blood donors & & $\begin{array}{l}A G A \\
\text { A }\end{array}$ & EMA & 2069 & 8 & 0.0039 \\
\hline Israeli, $2010^{59}$ & 2003 & Israel & Israel & 31.91 & 18 & Converience sampling & Miltary recruits & tTGA & $\mathrm{NA}$ & 850 & 9 & 0.0106 \\
\hline Varrson, $1999^{\circ 0}$ & 1994 & Sweden & $\begin{array}{l}\text { Umea-North } \\
\text { Sweden }\end{array}$ & 63.83 & $25-74$ & General population & & AGA & EMA & 1894 & 10 & 0.0053 \\
\hline Ivarsson, $2013^{6^{4}}$ & 2010 & Sweden & Sweden & 59.34 & 12 & General population & & tTGA & EMA & 5424 & 99 & 0.0183 \\
\hline Jansen, $2018^{62}$ & 2013 & The Netherlands & Rotterdam & 52.2 & 6 & General population & & tTGA & EMA & 4442 & 35 & 0.0079 \\
\hline 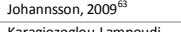 & 2007 & Iceland & Akureyri & 65.68 & $17-64$ & Blood donors & & tTGA & NA & 813 & 6 & 0.0074 \\
\hline 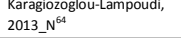 & ${ }^{2013}$ & Greece & Thessaloniki & 40.62 & 2.6 & General population & & tiGA & EMA & 598 & 7 & 0.0117 \\
\hline 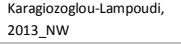 & 2013 & Greece & Agrinio & 38.62 & 2.6 & General population & & tTGA & EMA & 174 & 1 & 0.0057 \\
\hline $\begin{array}{l}\text { Karagiozoglou-Lampoudi, } \\
2013 \_s\end{array}$ & 2013 & Greece & Herakleion & 35.34 & 2.6 & General population & & tTGA & EMA & 308 & 0 & 0.0000 \\
\hline Katt, $2011^{\omega^{6}}$ & 2011 & USA & Natrona County & 42.86 & $>18$ & General population & & tTGA & EMA & 3850 & 34 & 0.0088 \\
\hline Khayyat, $2012^{2^{6}}$ & 2010 & Saudi Arabia & Jeddah & 21.49 & 14.78 & Blood donors & & tTGA & $\mathrm{NA}$ & 204 & 3 & 0.0147 \\
\hline Kochhar, $2011^{6^{\prime}}$ & 2011 & India & Chandigarh & 30.73 & $20-41$ & Blood donors & & tTGA & NA & 1610 & 9 & 0.0056 \\
\hline Kolho, $1998^{8^{88}}$ & 1996 & Finland & Helsinki & 60.18 & NA & General population & & EMA & NA & 1070 & 11 & 0.0103 \\
\hline Kondrashova, $2008^{69}$ & 2001 & Russia & 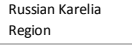 & 63.50 & 6-18 & General population & & tTGA & EMA & 1988 & 9 & 0.0045 \\
\hline Korponay-Szzabo, $1999^{10}$ & 1999 & Hungary & Budapest & 47.49 & 3.6 & General population & & EMA & $\mathrm{NA}$ & 427 & 6 & 0.0141 \\
\hline Korponay-Szabo, $2007^{14}$ & 2005 & Hungary & $\begin{array}{l}\text { Jass-Nagykkn- } \\
\text { Szolonk County }\end{array}$ & 47.23 & 6 & General population & & tTGA & EMA & 2690 & 33 & 0.0123 \\
\hline Kratere, $2013^{12}$ & 2002 & Germany & Leutkirch & 47.82 & 18.65 & General population & & tTGA & $\mathrm{NA}$ & 2157 & 17 & 0.0065 \\
\hline Laass, $2015^{33}$ & 2006 & Germany & Germany & 51.08 & 1-17 & General population & & tTGA & $N^{N A}$ & 12741 & 106 & 0.0083 \\
\hline Leja, $2015^{74}$ & 2012 & Latvia & Latvia & 56.90 & 24.74 & General population & & tTGA & EMA & 1444 & 5 & 0.0035 \\
\hline Lohi, 2007_-1 & 1980 & Finland & Finland & 62.98 & 30.95 & General population & & tTGA & EMA & 6993 & 76 & 0.0109 \\
\hline Lohi, 2007_2 & 2001 & Finland & Finland & 62.98 & $30-95$ & General population & & tTGA & EMA & 6402 & 124 & 0.0194 \\
\hline 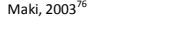 & 1994 & Finland & $\begin{array}{l}\text { Northern Finland, } \\
\text { Oulu }\end{array}$ & 65.05 & $7-16$ & General population & & tTGA & EMA & 4280 & 54 & 0.0126 \\
\hline Mankai, $2000^{n}$ & 2003 & Tunisia & Sousse & 35.83 & $16-63$ & Blood donors & & AGA & EMA & 2500 & 7 & 0.0028 \\
\hline Marine, $2009^{18}$ & 2005 & Spain & Terrassa & 41.56 & $30-40$ & Convenience sampling & $\begin{array}{l}\text { Workers in heatth } \\
\text { department }\end{array}$ & $t T G A+E M A$ & EMA & 1868 & 8 & 0.0043 \\
\hline Marine, 2011_ $1^{19}$ & 2007 & Spain & Catalonia & 44.63 & $1-19$ & General population & & tTGA & NA & 2994 & 38 & 0.0127 \\
\hline $\begin{array}{l}\text { Marine, 2011_2 } 2 \\
\text { Mcillan, } 1996.1^{80}\end{array}$ & 2007 & $\begin{array}{l}\text { Spain } \\
\text { UK }\end{array}$ & $\begin{array}{l}\text { Catatonia } \\
\text { Belfast }\end{array}$ & $\begin{array}{l}41.63 \\
54.53\end{array}$ & $\begin{array}{l}19.99 \\
15.64\end{array}$ & $\begin{array}{l}\text { General population } \\
\text { General poplutaion }\end{array}$ & & TTAA & NA & 3246 & 11 & 0.0034 \\
\hline $\begin{array}{l}\text { Mcinilan, } 19996_{-1}^{10} \\
\text { Melo, 20006 }\end{array}$ & ${ }_{2083} 2002$ & $\begin{array}{l}\text { UK } \\
\text { Brazil } \\
\end{array}$ & $\begin{array}{l}\text { Beflast } \\
\text { San Paulo }\end{array}$ & $\begin{array}{l}5.53 \\
23.55\end{array}$ & $\begin{array}{l}\begin{array}{l}15-64 \\
18-45\end{array} \\
\end{array}$ & $\begin{array}{l}\text { General popplation } \\
\text { Blood donors }\end{array}$ & & $\begin{array}{l}\text { EMA } \\
\text { tTGA }\end{array}$ & $\begin{array}{l}\text { NAA } \\
\text { EMA }\end{array}$ & $\begin{array}{l}1206 \\
3000\end{array}$ & $\begin{array}{l}19 \\
15\end{array}$ & $\frac{0.0158}{0.0050}$ \\
\hline Menardo, $2006^{82}$ & 2003 & Italy & Carcare & 44.55 & $13-90$ & $\begin{array}{l}\text { Bolodo conorors } \\
\text { General population }\end{array}$ & & tTGA & $\begin{array}{l}\text { ENA } \\
\text { EMA }\end{array}$ & 1002 & 13 & 0.00130 \\
\hline Mestkula, $1998^{83}$ & 1996 & Estonia & Southern Estonia & 57.94 & $9 \cdot 15$ & General population & & AGA & EMA & 487 & 0 & 0.0000 \\
\hline Montesanti, $1996^{84}$ & 1994 & Italy & Lucca & 43.88 & $10-15$ & General population & & AGA & EMA & 1073 & 4 & 0.0037 \\
\hline Moura, $2012^{85}$ & 2009 & Brazil & Recife & 8.06 & $18-30$ & Convenience sampling & & tTGA & EMA & 683 & 5 & 0.0059 \\
\hline Mustalahti, 2010_Finland & 2001 & Finland & Finland & 62.98 & 30.93 & General population & & tTGA & EMA & 6403 & 128 & 0.0200 \\
\hline $\begin{array}{l}\text { Mustalahti, } \\
\text { 2010_Germany } 1990\end{array}$ & 1990 & Germany & Ausburg & 48.34 & $25-74$ & General population & & tTGA & EMA & 4633 & 7 & 0.0015 \\
\hline $\begin{array}{l}\text { Mustalahti, } \\
\text { 2010_Germany2001 }\end{array}$ & 2001 & Germany & Ausburg & 48.34 & $25-74$ & General population & & tTGA & EMA & 4173 & 11 & 0.0026 \\
\hline Mustalahti, 2010_UKadults & 1987 & UK & Northern Ireland & 54.53 & $25-64$ & General population & & tTGA & EMA & 4781 & 69 & 0.0144 \\
\hline Mustalahti, 2010_Ukchild & & & Northern Ireland & & 12-15 & General population & & & EMA & 1975 & 17 & \\
\hline
\end{tabular}




\begin{tabular}{|c|c|c|c|c|c|c|c|c|c|c|c|}
\hline Myleus, 2009__und" & 2006 & Sweden & Lund & 55.78 & 12 & General population & tTGA & EMA & 3078 & 94 & 0.0305 \\
\hline Myleus, 2009_Norrkoping & 2006 & Sweden & Norrkoping & 58.59 & 12 & General population & tTGA & EMA & 912 & 25 & 0.0274 \\
\hline Myleus, 2009_Norrtaje & 2006 & Sweden & Norrtalie & 59.76 & 12 & General population & $t \in \mathbb{A}$ & EMA & 845 & 23 & 0.0272 \\
\hline Myleus, 2009_Umea & 2006 & Sweden & Umea & 63.83 & 12 & General population & tTGA & EMA & 1355 & 27 & 0.0199 \\
\hline Myleus, 2009_Vaxjo & 2006 & Sweden & Vaxjo & 56.94 & 12 & General population & tTGA & EMA & 1017 & 43 & 0.0423 \\
\hline Nenna, $2013^{88}$ & 2010 & Italy & Rome & 41.9 & 2.8 & General population & tTGA & EMA & 5733 & 74 & 0.0129 \\
\hline Not, $1998^{89}$ & 1996 & USA & $\begin{array}{l}\text { Baltimore, } \\
\text { Maryland }\end{array}$ & 39.3 & 19-48 & Blood donors & tTGA & EMA & 2000 & 8 & 0.0040 \\
\hline Nusier, 2010 & 2006 & Jordan & Irbid City & 32.56 & $6-10$ & General population & tTGA & EMA & 1985 & 16 & 0.0081 \\
\hline Oliveria, $2007^{92}$ & 2004 & Brazil & San Paulo & 23.55 & 18.65 & Blood donors & tTGA & $\mathrm{NA}$ & 3000 & 45 & 0.0150 \\
\hline 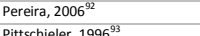 & 2001 & Brazil & Curitiba & 25.42 & 20.62 & Blood donors & tTGA & EMA & 2086 & 6 & 0.0029 \\
\hline $\begin{array}{l}\text { Pittschieler, 1996-93 } \\
\text { Pratei }\end{array}$ & 1996 & Italy & South Tyrol & 46.7 & $18-82$ & General population & AGA & EMA & 4615 & 9 & 0.0020 \\
\hline $\begin{array}{l}\text { Pratesi, 20003" } \\
\text { Ramakrishna, }\end{array}$ & 2000 & Brazil & $\begin{array}{l}\text { Brasilia } \\
\text { Tamil Nadu }\end{array}$ & 15.77 & $1-60$ & General population & EMA & NA & 4405 & 16 & 0.0036 \\
\hline $\begin{array}{l}\text { Ramakrishana, } \\
\text { 2016_TamilNahus }\end{array}$ & 2012 & India & & 12.26 & 18-100 & & & $\mathrm{NA}$ & 8973 & 12 & \\
\hline Ramakrishna, 2016_Haryana & 2013 & India & Haryana & 28.93 & 18-100 & General population & tTGA & NA & 6209 & 76 & 0.0086 \\
\hline Ramakrishna, 2016_Assam & ${ }^{2013}$ & India & Assam & 26.14 & 18-100 & General population & tTGA & NA & 8149 & 70 & 0.0122 \\
\hline Ravikumara, $2007^{76}$ & 2000 & uK & $\begin{array}{l}\text { Avon, Southwest } \\
\text { UK }\end{array}$ & 51.35 & 8 & General population & tTGA & EMA & 5470 & 57 & 0.0104 \\
\hline Remes-Troche, 2006" & 2004 & Mexico & Mexico City & 19.45 & $17-64$ & Blood donors & tTGA & $\mathrm{NA}$ & 1009 & 27 & 0.0268 \\
\hline Ress, $2011^{11^{86}}$ & 1999 & Estonia & Tartu County & 58.37 & $9 \cdot 15$ & General population & tTGA & $\mathrm{NA}$ & 1160 & 5 & 0.0043 \\
\hline Riestra, 2000"si & 1998 & Spain & Langreo, Austrias & 43.42 & $2-89$ & General population & AGA/NA & EMA & 1170 & 3 & 0.0026 \\
\hline Roka, 2007 & 2006 & Greece & Thessaly & 39.56 & $18-80$ & General population & tTGA & EMA & 2230 & 4 & 0.0018 \\
\hline $\begin{array}{l}\text { Rostami, } 199^{10101} \\
\text { Rutz, 20202102 }\end{array}$ & 1998 & $\begin{array}{l}\text { The Netherlands } \\
\text { Switzerand }\end{array}$ & $\begin{array}{l}\text { Arnhem, Nijmegen } \\
\text { Canton } S \text { St }\end{array}$ & 51.92 & $18-100$ & Blood donors & EMA & NA & 1000 & 3 & 0.0030 \\
\hline 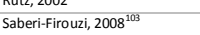 & 2004 & $\begin{array}{l}\text { Swrtzerland } \\
\text { Iran }\end{array}$ & $\begin{array}{l}\text { Canton or St Gallen } \\
\text { Shiraz }\end{array}$ & 29.61 & $20-83$ & $\begin{array}{l}\text { Generala poputation } \\
\text { General population }\end{array}$ & $\begin{array}{l}\text { tTGA } \\
\text { tTGA }\end{array}$ & $\begin{array}{l}\text { EMA } \\
\text { EMA }\end{array}$ & $\begin{array}{l}1440 \\
1440\end{array}$ & $\frac{11}{2}$ & $\begin{array}{l}0.0076 \\
0.0014\end{array}$ \\
\hline Sanders, $2003^{104}$ & 2001 & uK & South Yorkshire & 53.51 & $16-91$ & General population & tTGA & EMA & 1200 & 12 & 0.0100 \\
\hline Sardy, 2013 & 2002 & Hungary & Budapest & 47.49 & & Blood donors & tTGA & EMA & 4155 & 25 & 0.0060 \\
\hline Schweizer, $2004^{106}$ & 1997 & The Netherlands & $\begin{array}{l}\text { Amsterdam, } \\
\text { Doerinchem, } \\
\text { Mastricht }\end{array}$ & 52.24 & 20-59 & General population & tTGA & EMA & 1440 & 14 & 0.0090 \\
\hline Sezgin, 2016 & 2013 & Turkey & Mersin & 36.83 & $18-82$ & General population & tTGA & NA & 1554 & 12 & 0.0077 \\
\hline Shahbazkhan, 2003 & 1999 & Iran & Tehran & 35.7 & 18-65 & Blood donors & AGA & EMA & 2000 & 12 & 0.0060 \\
\hline Shamir, 2002 & 2001 & Israel & Istrael & 31.91 & 18-76 & Blood donors & tTGA & EMA & 1571 & 21 & 0.0134 \\
\hline 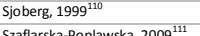 & 1997 & Sweden & Linkoping & 58.41 & $18-70$ & Blood donors & AGA & EMA & 1970 & 6 & 0.0030 \\
\hline $\begin{array}{l}\text { Szaftarska-Poplawska, 2009"111 } \\
\text { Tatar } 200^{112}\end{array}$ & 2009 & $\begin{array}{l}\text { Poland } \\
\text { Turkey }\end{array}$ & 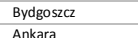 & 53.12 & $\begin{array}{l}7.10 \\
18.65 \\
18.5\end{array}$ & $\begin{array}{l}\text { General population } \\
\text { Blood donors o }\end{array}$ & $\begin{array}{lll}E M A \\
\text { tTAA }\end{array}$ & NA & $\begin{array}{l}3235 \\
2000\end{array}$ & 25 & $\begin{array}{l}0.0077 \\
0.0130\end{array}$ \\
\hline $\begin{array}{l}\text { Tatat, } 2000^{122} \\
\text { Tikkakkoski, } 2007^{113}\end{array}$ & $\begin{array}{l}2001 \\
2004\end{array}$ & $\begin{array}{l}\text { Turkey } \\
\text { Finland }\end{array}$ & $\begin{array}{l}\text { Ankara } \\
\text { Helsinki }\end{array}$ & 39.18 & $\begin{array}{l}18-65 \\
18.64\end{array}$ & $\begin{array}{l}\text { Blood donors } \\
\text { General population }\end{array}$ & $\begin{array}{l}t \in A \\
\operatorname{t\in A} A\end{array}$ & $\begin{array}{l}\text { NA } \\
\text { EMA }\end{array}$ & $\begin{array}{l}2000 \\
1900\end{array}$ & 36 26 & $\begin{array}{l}0.0130 \\
0.0189\end{array}$ \\
\hline Tommasini, $2004^{114}$ & 2000 & Italy & Trieste & 45.65 & $6-12$ & General population & tTGA & EMA & 3188 & 33 & 0.0104 \\
\hline Trevisiol, 1999 ${ }^{115}$ & 1998 & Italy & Trieste & 45.65 & 18-60 & Blood donors & EMA & NA & 4000 & 10 & 0.0025 \\
\hline Unalp-Arida, 2017_Midlat ${ }^{116}$ & 2014 & USA & Mid Latitude & 37.5 & 20-100 & General population & tTGA & EMA & 5392 & 21 & 0.0041 \\
\hline Unalp-Arida, 2017_Midatat & 2014 & USA & Mid Latitude & 37.5 & $6-19$ & General population & tTGA & EMA & 1232 & 5 & 0.0039 \\
\hline 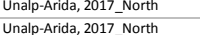 & 2014 & USA & North & $\begin{array}{l}45 \\
45 \\
45\end{array}$ & $20-100$ & $\begin{array}{l}\text { General population } \\
\text { General population }\end{array}$ & tTGA & EMA & 6720 & 51 & 0.0024 \\
\hline 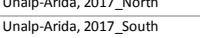 & 2014 & $\begin{array}{l}\text { USA } \\
\text { USA }\end{array}$ & $\begin{array}{l}\text { North } \\
\text { South }\end{array}$ & $\begin{array}{l}45 \\
32\end{array}$ & $\begin{array}{l}\text { 20-19 } \\
20-100\end{array}$ & $\begin{array}{l}\text { Generar popplation } \\
\text { General population }\end{array}$ & $\begin{array}{l}\text { titA } \\
\text { tTGA }\end{array}$ & $\begin{array}{l}\text { EMA } \\
\text { EMA }\end{array}$ & $\begin{array}{l}1455 \\
5943\end{array}$ & $\begin{array}{r}16 \\
7\end{array}$ & $\begin{array}{l}0.0351 \\
0.0015\end{array}$ \\
\hline Unalp-Arida, 201__South & 2014 & USA & South & 32 & 6-19 & General population & tTGA & EMA & 1533 & 9 & 0.0046 \\
\hline Utivama, $2010^{11 / 7}$ & 2010 & Brazil & $\begin{array}{l}\text { Mangueirinha } \\
\text { Reserve }\end{array}$ & 25.56 & 2.86 & General population & EMA & NA & 180 & 0 & 0.0000 \\
\hline Vancikova, $2002^{118}$ & 2001 & Crech Republic & Prague & 50.07 & 18.60 & Blood donors & tTGA & EMA & 1312 & 6 & 0.0046 \\
\hline Verkasalo, $2005^{119}$ & 2001 & Finland & Finland & 62.98 & 24-39 & General population & tTGA & EMA & 2427 & 29 & 0.0119 \\
\hline Vijen, 2012 & 2006 & Beggium & Belgium & 46.7 & 1.19 & General population & tTGA & EMA & 1159 & 4 & 0.0035 \\
\hline Vilippula, $2009^{121}$ & 2002 & Finland & PajajatHame & 61.05 & $52-74$ & General population & tTGA & EMA & 2815 & 44 & 0.0156 \\
\hline Volta, 2001 $1^{122}$ & 1992 & Italy & Campogalliano & 44.69 & 12-25 & General population & EMA & $N A$ & 784 & 10 & 0.0128 \\
\hline Volta, 2001__2 & 1992 & taly & Campogalliano & 44.69 & $25-65$ & General population & EMA & NA & 2699 & 10 & 0.0037 \\
\hline Waker, 20101013 & 1998 & Sweden & $\begin{array}{l}\text { Kalix and } \\
\text { Haparanda }\end{array}$ & 65.87 & $20-80$ & General population & tTGA & EMA & 1000 & 18 & 0.0180 \\
\hline Weile, 2001_Denmark ${ }^{124}$ & 2001 & Denmark & Denmark & 55.62 & 18-65 & Blood donors & AGA & EMA & 1573 & 4 & 0.0025 \\
\hline Weile, 2001_Sweden & 2001 & Sweden & Sweden & 59.34 & $18-65$ & Blood donors & AGA & EMA & 1866 & 5 & 0.0027 \\
\hline West, $203^{125}$ & 1995 & UK & Cambridge & 52.21 & $45-76$ & General population & EMA & TGA & 7550 & 91 & 0.0121 \\
\hline Yap, $2015^{2126}$ & 2014 & Malaysia & Kuala Lumpur & 3.15 & $18-30$ & General population & tTGA & EMA & 562 & 7 & 0.0125 \\
\hline 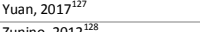 & 2013 & China & Nanchang & 29 & $18-20$ & General population & DGP & TGA & 19778 & 72 & 0.0036 \\
\hline 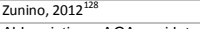 & 2011 & & Bergamo & 45.7 & $19 \cdot 62$ & Blood donors & & & 18498 & 76 & 0.0041 \\
\hline
\end{tabular}




\section{Supplemental Material 6. List of References}

1. Aberg A-K, Olcen P. Serologic screening for celiac disease in children: a comparison between established assays and tests with deamidated gliadin-derived peptides plus conjugates for both IgA and IgG antibodies. Apmis. 2009;117(11):808-813.

2. Abu-Zeid YA, Jasem WS, Lebwohl B, Green PH, EIGhazali G. Seroprevalence of celiac disease among United Arab Emirates healthy adult nationals: a gender disparity. World J Gastroenterol. 2014;20(42):15830-15836.

3. Abu-Zekry M, Kryszak D, Diab M, Catassi C, Fasano A. Prevalence of celiac disease in Egyptian children disputes the eastwest agriculture-dependent spread of the disease. J Pediatr Gastroenterol Nutr. 2008;47(2):136-140.

4. Agardh D, Carlsson A, Lynch K, Axelsson I, Lemmark A, Ivarsson SA. Using radioligand-binding assays to measure tissue transglutaminase autoantibodies in young children. Acta Paediatr. 2004;93(8):1046-1051.

5. Agardh D. Antibodies against synthetic deamidated gliadin peptides and tissue transglutaminase for the identification of childhood celiac disease. Clin Gastroenterol Hepatol. 2007;5(11):1276-1281.

6. Agardh D, Bjorck S, Agardh C-D, Lidfeldt J. Coeliac disease-specific tissue transglutaminase autoantibodies are associated with osteoporosis and related fractures in middle-aged women. Scand J Gastroenterol. 2009;44(5):571-578.

7. Akbari MR, Mohammadkhani A, Fakheri $\mathrm{H}$, et al. Screening of the adult population in Iran for coeliac disease: comparison of the tissue-transglutaminase antibody and anti-endomysial antibody tests. Eur J Gastroenterol Hepatol. 2006;18(11):11811186.

8. Al Hatlani MM. Prevalence of celiac disease among symptom-free children from the Eastern Province of Saudi Arabia. Saudi j. 2015;21(6):367-371.

9. Al-Ajlan AS. Screening of coeliac disease in undetected adults and patients diagnosed with irritable bowel syndrome in Riyadh, Saudi Arabia. Saudi J Biol Sci. 2016;23(4):462-466.

10. Alarida K, Harown J, Ahmaida A, et al. Coeliac disease in Libyan children: a screening study based on the rapid determination of anti-transglutaminase antibodies. Dig Liver Dis. 2011;43(9):688-691.

11. Alencar ML, Ortiz-Agostinho CL, Nishitokukado L, et al. Prevalence of celiac disease among blood donors in Sao Paulo: the most populated city in Brazil. Clinics. 2012;67(9):1013-1018.

12. Alessandrini S, Giacomoni E, Muccioli F. Mass population screening for celiac disease in children: the experience in Republic of San Marino from 1993 to 2009. Ital. 2013;39:67.

13. Al-Hussaini A, Troncone R, Khormi M, et al. Mass Screening for Celiac Disease Among School-aged Children: Toward Exploring Celiac Iceberg in Saudi Arabia. J Pediatr Gastroenterol Nutr. 2017;65(6):646-651.

14. Aljebreen AM, Almadi MA, Alhammad A, Al Faleh FZ. Seroprevalence of celiac disease among healthy adolescents in Saudi Arabia. World J Gastroenterol. 2013;19(15):2374-2378.

15. Almazan MV, Ortega E, Moreno Torres R, et al. Diagnostic screening for subclinical celiac disease using a rapid test in children aged 2-4. Pediatr Res. 2015;78(3):280-285.

16. Almeida LM, Castro LC, Uenishi RH, et al. Decreased prevalence of celiac disease among Brazilian elderly. World J Gastroenterol. 2013;19(12):1930-1935. 
17. Anderson RP, Henry MJ, Taylor R, et al. A novel serogenetic approach determines the community prevalence of celiac disease and informs improved diagnostic pathways. BMC Med. 2013;11:188.

18. Antunes $\mathrm{H}$, Abreu I, Nogueiras A, et al. [First determination of the prevalence of celiac disease in a Portuguese population]. Acta medica portuguesa. 2006;19(2):115-120.

19. Bahari A, Karimi M, Sanei-Moghaddam I, Firouzi F, Hashemi M. Prevalence of celiac disease among blood donors in Sistan and Balouchestan Province, Southeastern Iran. Arch Iran Med. 2010;13(4):301-305.

20. Bdioui F, Sakly N, Hassine M, Saffar H. Prevalence of celiac disease in Tunisian blood donors. Gastroenterologie Clinique et Biologique. 2006;30(1):33-36.

21. Bonamico M, Nenna R, Montuori M, et al. First salivary screening of celiac disease by detection of anti-transglutaminase autoantibody radioimmunoassay in 5000 Italian primary schoolchildren. $J$ Pediatr Gastroenterol Nutr. 2011;52(1):17-20.

22. Borch K, Grodzinsky E, Petersson F, Jonsson KA, Mardh S, Valdimarsson T. Prevalence of coeliac disease and relations to Helicobacter pylori infection and duodenitis in a Swedish adult population sample: A histomorphological and serological survey. Inflammopharmacology. 2000;8(4):341-350.

23. Canavan C, Logan RF, Khaw KT, West J. No difference in mortality in undetected coeliac disease compared with the general population: a UK cohort study. Aliment Pharmacol Ther. 2011;34(8):1012-1019.

24. Carlsson AK, Axelsson IE, Borulf SK, Bredberg AC, Ivarsson SA. Serological screening for celiac disease in healthy 2.5-yearold children in Sweden. Pediatrics. 2001;107(1):42-45.

25. Castano L, Blarduni E, Ortiz L, et al. Prospective population screening for celiac disease: high prevalence in the first 3 years of life. J Pediatr Gastroenterol Nutr. 2004;39(1):80-84.

26. Catassi C, Ratsch IM, Fabiani E, et al. Coeliac disease in the year 2000: exploring the iceberg. Lancet. 1994;343(8891):200203.

27. Catassi C, Fanciulli G, D'Appello AR, et al. Antiendomysium versus antigliadin antibodies in screening the general population for coeliac disease. Scand J Gastroenterol. 2000;35(7):732-736.

28. Catassi C, Kryszak D, Bhatti B, et al. Natural history of celiac disease autoimmunity in a USA cohort followed since 1974. Ann Med. 2010;42(7):530-538.

29. Chin MW, Mallon DF, Cullen DJ, Olynyk JK, Mollison LC, Pearce CB. Screening for coeliac disease using anti-tissue transglutaminase antibody assays, and prevalence of the disease in an Australian community. Med J Aust. 2009;190(8):429432.

30. Choung RS, Larson SA, Khaleghi S, et al. Prevalence and Morbidity of Undiagnosed Celiac Disease From a CommunityBased Study. Gastroenterology. 2017;152(4):830-839.e835.

31. Cilleruelo Pascual ML, Roman Riechmann E, Jimenez Jimenez J, et al. [Silent celiac disease: exploring the iceberg in the school-aged population]. An Esp Pediatr. 2002;57(4):321-326.

32. Cook HB, Burt MJ, Collett JA, Whitehead MR, Frampton CM, Chapman BA. Adult coeliac disease: prevalence and clinical significance. J Gastroenterol Hepatol. 2000;15(9):1032-1036.

33. Corazza GR, Andreani ML, Biagi F, et al. The smaller size of the 'coeliac iceberg' in adults. Scand J Gastroenterol. 1997;32(9):917-919. 
34. Csizmadia CGDS, Mearin ML, Von Blomberg BME, Brand R, Verloove-Vanhorick SP. An iceberg of childhood coeliac disease in the Netherlands. Lancet. 1999;353(9155):813-814.

35. da Conceicao-Machado MEP, Santana MLP, Silva RdCR, et al. Serologic screening of celiac disease in adolescents. Rev. 2015;18(1):149-156.

36. Dalgic B, Sari S, Basturk B, et al. Prevalence of celiac disease in healthy Turkish school children. The American journal of gastroenterology. 2011;106(8):1512-1517.

37. Demirceken FG, Kansu A, Kuloglu Z, Girgin N, Guriz H, Ensari A. Human tissue transglutaminase antibody screening by immunochromatographic line immunoassay for early diagnosis of celiac disease in Turkish children. Turk $J$ Gastroenterol. 2008;19(1):14-21.

38. Dehghani SM, Haghighat M, Mobayen A, Rezaianzadeh A, Geramizadeh B. Prevalence of celiac disease in healthy Iranian school children. Annals of Saudi medicine. 2013;33(2):159-161.

39. Edlinger-Horvat C, Fidler D, Huber W-D, et al. Serological screening for undiagnosed coeliac disease in male adolescents in lower Austria: a population based study. Eur J Pediatr. 2005;164(1):52-53.

40. El-Hadi S, Tuthill D, Lewis E, et al. Unrecognised coeliac disease is common in healthcare students. Archives of Disease in Childhood. 2004;89(9):842.

41. Ertekin V, Selimoglu MA, Kardas F, Aktas E. Prevalence of celiac disease in Turkish children. J Clin Gastroenterol. 2005;39(8):689-691.

42. Fabiani E, Catassi C, International Working $G$. The serum IgA class anti-tissue transglutaminase antibodies in the diagnosis and follow up of coeliac disease. Results of an international multi-centre study. International Working Group on Eu-tTG. Eur $J$ Gastroenterol Hepatol. 2001;13(6):659-665.

43. Farahmand F, Mir-Nasseri MM, Shahraki T, et al. Prevalence of occult celiac disease in healthy Iranian school age children. Arch Iran Med. 2012;15(6):342-345

44. Fukunaga M, Ishimura N, Fukuyama C, et al. Celiac disease in non-clinical populations of Japan. J Gastroenterol. 2017;07:07.

45. Galvan JA, Castaneda C, Rodriguez EA, et al. Screening for celiac disease in a healthy Cuban children cohort from Pinar del Rio province. Biotecnologia Aplicada. 2010;27(4):291-293.

46. Gandolfi L, Pratesi R, Cordoba JC, Tauil PL, Gasparin M, Catassi C. Prevalence of celiac disease among blood donors in Brazil. American Journal of Gastroenterology. 2000;95(3):689-692.

47. Garcia Novo MD, Garfia C, Acuna Quiros MD, et al. [Prevalence of celiac disease in apparently healthy blood donors in the autonomous community of Madrid]. Rev Esp Enferm Dig. 2007;99(6):337-342.

48. Godfrey JD, Brantner TL, Brinjikji W, et al. Morbidity and mortality among older individuals with undiagnosed celiac disease. Gastroenterology. 2010;139(3):763-769.

49. Gomez JC, Selvaggio GS, Viola M, et al. Prevalence of celiac disease in Argentina: screening of an adult population in the La Plata area. American Journal of Gastroenterology. 2001;96(9):2700-2704.

50. Guariso G, Plebani M, Signorini R, et al. [Silent celiac disease: results of a study in secondary schools of Padua]. Pediatr Med Chir. 1997;19(2):95-98. 
51. Gursoy S, Guven K, Simsek T, et al. The prevalence of unrecognized adult celiac disease in Central Anatolia. J Clin Gastroenterol. 2005;39(6):508-511.

52. Handel N, Mothes T, Petroff D, et al. Will the Real Coeliac Disease Please Stand Up? Coeliac Disease Prevalence in the German LIFE Child Study. J Pediatr Gastroenterol Nutr. 2018;12:12.

53. Ben Hariz M, Kallel-Sellami M, Kallel L, et al. Prevalence of celiac disease in Tunisia: mass-screening study in schoolchildren. Eur J Gastroenterol Hepatol. 2007;19(8):687-694.

54. Hariz MB, Laadhar L, Kallel-Sellami M, et al. Celiac disease in Tunisian children: a second screening study using a "new generation" rapid test. Immunol Invest. 2013;42(4):356-368.

55. Henker J, Losel A, Conrad K, Hirsch T, Leupold W. [Prevalence of asymptommatic coeliac disease in children and adults in the Dresden region of Germany]. Dtsch Med Wochenschr. 2002;127(28-29):1511-1515.

56. Hogen Esch CE, Rosen A, Auricchio R, et al. The PreventCD Study design: Towards new strategies for the prevention of coeliac disease. European Journal of Gastroenterology and Hepatology. 2010;22(12):1424-1430.

57. Horwitz A, Skaaby T, Karhus LL, et al. Screening for celiac disease in Danish adults. Scand J Gastroenterol. 2015;50(7):824831.

58. Hovdenak N, Hovlid E, Aksnes L, Fluge G, Erichsen MM, Eide J. High prevalence of asymptomatic coeliac disease in Norway: a study of blood donors. Eur J Gastroenterol Hepatol. 1999;11(2):185-187.

59. Israeli E, Hershcovici T, Grotto I, Rouach Z, Branski D, Goldin E. Prevalence of celiac disease in an adult Jewish population in Israel. Isr Med Assoc J. 2010;12(5):266-269.

60. Ivarsson A, Persson LA, Juto P, Peltonen M, Suhr O, Hernell O. High prevalence of undiagnosed coeliac disease in adults: a Swedish population-based study. J Intern Med. 1999;245(1):63-68.

61. Ivarsson A, Myleus A, Norstrom F, et al. Prevalence of childhood celiac disease and changes in infant feeding. Pediatrics. 2013;131(3):e687-694.

62. Jansen $\mathrm{M}$, van Zelm M, Groeneweg $\mathrm{M}$, et al. The identification of celiac disease in asymptomatic children: the Generation $\mathrm{R}$ Study. J Gastroenterol. 2018;53(3):377-386.

63. Johannsson GF, Kristjansson G, Cariglia N, Thorsteinsson V. The prevalence of celiac disease in blood donors in Iceland. Dig Dis Sci. 2009;54(2):348-350.

64. Karagiozoglou-Lampoudi T, Zellos A, Vlahavas G, et al. Screening for coeliac disease in preschool Greek children: the feasibility study of a community-based project. Acta Paediatr. 2013;102(7):749-754.

65. Katz KD, Rashtak S, Lahr BD, et al. Screening for celiac disease in a North American population: sequential serology and gastrointestinal symptoms. American Journal of Gastroenterology. 2011;106(7):1333-1339.

66. Khayyat YM. Serologic markers of gluten sensitivity in a healthy population from the western region of Saudi Arabia. Saudi $j$. 2012;18(1):23-25.

67. Kochhar R, Sachdev S, Kochhar R, et al. Prevalence of coeliac disease in healthy blood donors: a study from north India. Dig Liver Dis. 2012;44(6):530-532

68. Kolho KL, Farkkila MA, Savilahti E. Undiagnosed coeliac disease is common in Finnish adults. Scand J Gastroenterol. 1998;33(12):1280-1283. 
69. Kondrashova A, Mustalahti K, Kaukinen $\mathrm{K}$, et al. Lower economic status and inferior hygienic environment may protect against celiac disease. Ann Med. 2008;40(3):223-231.

70. Korponay-Szabo IR, Kovacs JB, Czinner A, Goracz G, Vamos A, Szabo T. High prevalence of silent celiac disease in preschool children screened with IgA/lgG antiendomysium antibodies. J Pediatr Gastroenterol Nutr. 1999;28(1):26-30

71. Korponay-Szabo IR, Szabados K, Pusztai J, et al. Population screening for coeliac disease in primary care by district nurses using a rapid antibody test: diagnostic accuracy and feasibility study. BMJ (Clinical research ed). 2007;335(7632):1244-1247.

72. Kratzer W, Kibele M, Akinli A, et al. Prevalence of celiac disease in Germany: a prospective follow-up study. World J Gastroenterol. 2013;19(17):2612-2620.

73. Laass MW, Rober N, Range U, Nos L, Roggenbuck D, Conrad K. Loss and Gain of Tolerance to Pancreatic Glycoprotein 2 in Celiac Disease. PLOS ONE. 2015;10(6):e0128104.

74. Leja M, Shums Z, Nikitina-Zake L, et al. Prevalence estimation of celiac disease in the general adult population of Latvia using serology and HLA genotyping. United European Gastroenterol. 2015;3(2):190-199.

75. Lohi S, Mustalahti K, Kaukinen K, et al. Increasing prevalence of coeliac disease over time. Aliment Pharmacol Ther. 2007;26(9):1217-1225.

76. Maki M, Mustalahti K, Kokkonen J, et al. Prevalence of Celiac disease among children in Finland. N Engl J Med. 2003;348(25):2517-2524.

77. Mankai A, Landolsi H, Chahed A, et al. Celiac disease in Tunisia: serological screening in healthy blood donors. Pathol Biol (Paris). 2006;54(1):10-13.

78. Marine M, Farre C, Alsina M, et al. An epidemiological study of celiac disease (CD) adjusted for age and sex to the reference population suggests a high frequency of evolution towards latency. Gastroenterology. 2009;1):A473.

79. Marine M, Farre C, Alsina M, et al. The prevalence of coeliac disease is significantly higher in children compared with adults. Aliment Pharmacol Ther. 2011;33(4):477-486.

80. McMillan SA, Watson RP, McCrum EE, Evans AE. Factors associated with serum antibodies to reticulin, endomysium, and gliadin in an adult population. Gut. 1996;39(1):43-47.

81. Melo SBC, Fernandes MIM, Peres LC, Troncon LEA, Galvao LC. Prevalence and demographic characteristics of celiac disease among blood donors in Ribeirao Preto, State of Sao Paulo, Brazil. Dig Dis Sci. 2006;51(5):1020-1025.

82. Menardo G, Brizzolara R, Bonassi S, et al. Population screening for coeliac disease in a low prevalence area in Italy. Scand J Gastroenterol. 2006;41(12):1414-1420.

83. Metskula K, Grunberg H, Uibo O, Talja I, Uibo R. Antigliadin antibodies and autoantibodies among 9, 12 and 15 year-old schoolchildren. Central-European Journal of Immunology. 1998;23(3-4):197-202.

84. Montesanti M, Domenici R, Matteucci L, Mei E. [Screening for celiac disease in children attending secondary school around Lucca]. Minerva Pediatr. 1996;48(11):475-483.

85. Moura ACA, de Castro-Antunes MM, de Lima LAM, Nobre JMM, Motta MEFA, da Silva GAP. Serological triage for celiac disease in adolescents and young adults attending university. Rev Bras Saude Matern Infant. 2012;12(2):121-126.

86. Mustalahti K, Catassi C, Reunanen A, et al. The prevalence of celiac disease in Europe: results of a centralized, international mass screening project. Ann Med. 2010;42(8):587-595. 
87. Myleus A, Ivarsson A, Webb C, et al. Celiac disease revealed in $3 \%$ of Swedish $12-y e a r-o l d s$ born during an epidemic. $J$ Pediatr Gastroenterol Nutr. 2009;49(2):170-176.

88. Nenna R, Petrarca L, Tiberti C, et al. Prevalence and clinical pictures of the disease in Italy: Results of the salivary screening United European Gastroenterol. 2013;1):A582.

89. Not T, Horvath K, Hill ID, et al. Celiac disease risk in the USA: high prevalence of antiendomysium antibodies in healthy blood donors. Scand J Gastroenterol. 1998;33(5):494-498.

90. Nusier MK, Brodtkorb HK, Rein SE, Odeh A, Radaideh AM, Klungland H. Serological screening for celiac disease in schoolchildren in Jordan. Is height and weight affected when seropositive? Ital. 2010;36:16.

91. Oliveira RP, Sdepanian VL, Barreto JA, et al. High prevalence of celiac disease in Brazilian blood donor volunteers based on screening by IgA antitissue transglutaminase antibody. European Journal of Gastroenterology and Hepatology. 2007;19(1):43-49.

92. Pereira MAG, Ortiz-Agostinho CL, Nishitokukado I, et al. Prevalence of celiac disease in an urban area of Brazil with predominantly European ancestry. World J Gastroenterol. 2006;12(40):6546-6550.

93. Pittschieler K, Ladinser B. Coeliac disease: screened by a new strategy. Acta Paediatr Suppl. 1996:412:42-45

94. Pratesi R, Gandolfi L, Garcia SG, et al. Prevalence of coeliac disease: unexplained age-related variation in the same population. Scand J Gastroenterol. 2003;38(7):747-750.

95. Ramakrishna BS, Makharia GK, Chetri K, et al. Prevalence of Adult Celiac Disease in India: Regional Variations and Associations. American Journal of Gastroenterology. 2016;111(1):115-123.

96. Ravikumara M, Nootigattu VKT, Sandhu BK. Ninety percent of celiac disease is being missed. J Pediatr Gastroenterol Nutr. 2007;45(4):497-499.

97. Remes-Troche JM, Ramirez-Iglesias MT, Rubio-Tapia A, Alonso-Ramos A, Velazquez A, Uscanga LF. Celiac disease could be a frequent disease in Mexico: prevalence of tissue transglutaminase antibody in healthy blood donors. $J$ Clin Gastroenterol. 2006:40(8):697-700.

98. Ress K, Harro J, Uibo O, Uibo R. Use of a fully automated immunoassay for celiac disease screening in a pediatric population. Clinical chemistry and laboratory medicine. 2011;49(6):983-987.

99. Riestra S, Fernandez E, Rodrigo L, Garcia S, Ocio G. Prevalence of Coeliac disease in the general population of northern Spain. Strategies of serologic screening. Scand J Gastroenterol. 2000;35(4):398-402.

100. Roka V, Potamianos SP, Kapsoritakis AN, et al. Prevalence of coeliac disease in the adult population of central Greece. Eur J Gastroenterol Hepatol. 2007;19(11):982-987.

101. Rostami K, Mulder CJ, Werre JM, et al. High prevalence of celiac disease in apparently healthy blood donors suggests a high prevalence of undiagnosed celiac disease in the Dutch population. Scand J Gastroenterol. 1999;34(3):276-279.

102. Rutz R, Ritzler E, Fierz W, Herzog D. Prevalence of asymptomatic celiac disease in adolescents of eastern Switzerland. Swiss Med Wkly. 2002;132(3-4):43-47.

103. Saberi-Firouzi M, Omrani G, Nejabat M, Mehrabani D, Khademolhosseini F. Prevalence of celiac disease in Shiraz, southern Iran. Saudi j. 2008;14(3):135-138. 
104. Sanders DS, Patel D, Stephenson TJ, et al. A primary care cross-sectional study of undiagnosed adult coeliac disease. Eur J Gastroenterol Hepatol. 2003;15(4):407-413.

105. Sardy M, Kornsee Z, Kelemen D, Papp S, Medvecz M, Karpati S. Celiac disease screening among healthy blood donors in Hungary. Z Gastroenterol. 2013;51(11):1235-1239.

106. Schweizer JJ, von Blomberg BME, Bueno-de Mesquita HB, Mearin ML. Coeliac disease in The Netherlands. Scand J Gastroenterol. 2004;39(4):359-364.

107. Sezgin O, Saritas B, Aydin I, Sasmaz T, Linke ES. Celiac disease prevalence in Turkey: A population based cross-sectional study. Acta Medica Mediterranea. 2016;32(3):719-727.

108. Shahbazkhani B, Malekzadeh R, Sotoudeh M, et al. High prevalence of coeliac disease in apparently healthy Iranian blood donors. Eur J Gastroenterol Hepatol. 2003;15(5):475-478.

109. Shamir R, Lerner A, Shinar E, et al. The use of a single serological marker underestimates the prevalence of celiac disease in Israel: a study of blood donors. American Journal of Gastroenterology. 2002;97(10):2589-2594.

110. Sjoberg K, Eriksson S. Regional differences in coeliac disease prevalence in Scandinavia? Scand J Gastroenterol. 1999;34(1):41-45

111. Szaflarska-Poplawska A, Parzecka M, Muller L, Placek W. Screening for celiac disease in Poland. Med Sci Monit. 2009;15(3):PH7-11.

112. Tatar G, Elsurer R, Simsek H, et al. Screening of tissue transglutaminase antibody in healthy blood donors for celiac disease screening in the Turkish population. Dig Dis Sci. 2004;49(9):1479-1484.

113. Tikkakoski S, Savilahti E, Kolho K-L. Undiagnosed coeliac disease and nutritional deficiencies in adults screened in primary health care. Scand J Gastroenterol. 2007;42(1):60-65.

114. Tommasini A, Not T, Kiren V, et al. Mass screening for coeliac disease using antihuman transglutaminase antibody assay. Archives of Disease in Childhood. 2004;89(6):512-515.

115. Trevisiol C, Not T, Berti I, et al. Screening for coeliac disease in healthy blood donors at two immuno-transfusion centres in north-east Italy. Ital J Gastroenterol. 1999;31(7):584-586.

116. Unalp-Arida A, Ruhl CE, Choung RS, Brantner T, Murray JA. Prevalence and factors associated with celiac disease and a gluten-free diet in the United States population. Gastroenterology. 2016;1):S484-S485.

117. Utiyama SRdR, Ribas JLC, Nisihara RM, Kotze LMdS, de Messias-Reason IJ. Celiac disease in native Indians from Brazil: A clinical and epidemiological survey. N A J Med Sci (Hamilt). 2010;2(3):138-142.

118. Vancikova Z, Chlumecky V, Sokol D, et al. The serologic screening for celiac disease in the general population (blood donors) and in some high-risk groups of adults (patients with autoimmune diseases, osteoporosis and infertility) in the Czech republic. Folia Microbiol (Praha). 2002;47(6):753-758.

119. Verkasalo MA, Raitakari OT, Viikari J, Marniemi J, Savilahti E. Undiagnosed silent coeliac disease: a risk for underachievement? Scand J Gastroenterol. 2005;40(12):1407-1412.

120. Vijgen S, Alliet P, Gillis P, Declercq P, Mewis A. Seroprevalence of celiac disease in Belgian children and adolescents. Acta Gastroenterol Belg. 2012;75(3):325-330. 
121. Vilppula A, Collin P, Maki M, et al. Undetected coeliac disease in the elderly: a biopsy-proven population-based study. Dig Liver Dis. 2008;40(10):809-813.

122. Volta U, Bellentani S, Bianchi FB, et al. High prevalence of celiac disease in Italian general population. Dig Dis Sci. 2001;46(7):1500-1505.

123. Walker MM, Murray JA, Ronkainen J, et al. Detection of Celiac Disease and Lymphocytic Enteropathy by Parallel Serology and Histopathology in a Population-Based Study. Gastroenterology. 2010;139(1):112-119.

124. Weile I, Grodzinsky E, Skogh T, Jordal R, Cavell B, Krasilnikoff PA. High prevalence rates of adult silent coeliac disease, as seen in Sweden, must be expected in Denmark. Apmis. 2001;109(11):745-750.

125. West J, Logan RFA, Hill PG, et al. Seroprevalence, correlates, and characteristics of undetected coeliac disease in England Gut. 2003;52(7):960-965.

126. Yap TWC, Chan WK, Leow AHR, et al. Prevalence of serum celiac antibodies in a multiracial asian population - A first study in the Young Asian adult population of Malaysia. PLoS ONE. 2015;10 (3) (no pagination)(e0121908).

127. Yuan J, Zhou C, Gao J, et al. Prevalence of Celiac Disease Autoimmunity Among Adolescents and Young Adults in China. Clin Gastroenterol Hepatol. 2017;19:19.

128. Zunino F, Alessio MG, Giussani B, et al. Screening of the celiac disease (CD) among blood donors in the Bergamo province: Preliminary data on 18.498 subjects. [Italian]. Biochimica Clinica. 2012;36(5):349-357. 